\title{
Geographic Endowment, Corruption, and Economic Development
}

\author{
Sazzadul Arefin \\ College of Economics and Trade, Hunan University, Changsha, Hunan, China \\ E-mail: showmikju@gmail.com
}

Received: October 25, 2018 Accepted: November 15, 2018 Published: December 21, 2018

doi:10.5296/ber.v9i1.14080

URL: https://doi.org/10.5296/ber.v9i1.14080

\begin{abstract}
Corruption plays an important role in determining the effectiveness and quality of the institution, and growth. This paper investigates the linkage between corruption, various measures of geographical endowments and economic growth. I use corruption as a proxy for institutional quality and try to solve the endogeneity problem by Instrumental Variable approach as 2SLS for panel data for a sample of 192 countries and showed that corruption matters for economic growth. The results indicate that graphical endowments explain cross-country variation in economic development through their effect on corruption even when I control for other historical and cultural factors. Thus, when considering making policy for developing or developed countries much attention should be paid to this fact.
\end{abstract}

Keywords: Economic Development, Corruption, Geographic Endowment, Two Stage Least Square (2SLS)

\section{Introduction}

In recent years, the growing number of interest among scholars and policymaker on corruption and growth has been seen on cross-country measurement on institutional quality and good governance. Corruption seems to play an important role in many factors especially in determining the effectiveness and quality of the institution, and the GDP growth rate. In this study, I examine what determines corruption and how it's affecting the economic growth. In accordance with these many scholars also argued that there are a geographical effect and policy effect that determines economic growth. Specifically, I investigate the relationship the effect of geographical endowments and historical factors with corruption and economic growth.

Corruption is a serious global problem. No country in the world is free from that. According to the Transparency International's report, Bangladesh ranked the most corrupt country from 
2001 to 2005 for five consecutive years achieving the lowest score in CPI. On the other hand, Denmark ranked as the corruption free country by perfectly scoring 10 in the corruption score in 1998 and 1999. Finland achieves the same score in 2000. This implies these two counties is completely corruption free, is it? Countries like Canada managed to get a higher score of 8 to 9 from the period from 1996 to 2013. Malaysia and South Africa managed to get the average score of 4 to 6 in the period.

Why some economy is doing much better than other? Why some economy is succeeded in controlling corruption, while others have not? The main purpose of this research is to asses empirically different theories of how geographical endowments, corruption (institutional efficiency), history and culture influence economic development.

Geographic differences play an important role in economic performers of the various societies and it forms a pattern that is widely recognized by the scholars especially in the recent economic times. Two hypotheses emerge from this concept. One believes in the direct effect of geography conditions and that closely focus on the association of economic growth to geographies such as climate, disease environment, soil quality, or access to markets, and on the availability and productivity of labour, education, and protection of property rights and other factors of production. The pioneer for this thought is (Daron Acemoglu, Johnson, \& Robinson, 2012; Machiavelli, n.d.,; Montesquieu \& de Secondat, n.d.,; Gallup \& Sachs, 2000; Limao, 2001; Galbraith, 1951; Sachs, Jeffrey D and Warner, 2001) And the other believe in the indirect effect of geography by looking at the effects of geography and factor endowments through the effect of the effectiveness of institutions involved in the process of economic growth. This hypothesis can be found in the work of Daron Acemoglu et al., 2012; Iyigun, 2005; Easterly, William and Levine, 2003; Beck \& Laeven, 2006; Newman, 1973. My hypothesis is for this paper is the former one.

Majority of analysts of the economic history of development agree that institutions and human capital is the prerequisite factors for development in the world. The institution view holds that every aspect of factors like geography, culture, history, ethnic diversity impact on economic development runs through inevitable institutions which determine the policy and runs the economic activity. If the institution is rent-seeking and corruption prevails underdevelopment is inevitable. (Greenberg, Carey, Zobler, \& Hordon, 1971; Engerman \& Sokoloff, 2002; Bulte, Damania, \& Deacon, 2005; D. Acemoglu, Johnson, \& Robinson, 2002; Daron Acemoglu et al., 2012; Glaeser, La Porta, Lopez-de-Silanes, \& Shleifer, 2004; Wietzke, 2015; Sokoloff \& Engerman, 2000) all agreed that institution matters for growth. It appears that the impact of natural resources on the development of a country is mainly indirect, occurring through channels of institutional quality and corruption. It is the institution that runs the economy of a county and makes policies. That is the reason the institutions have to be efficient and free of bias and problems such as corruption.

This paper addresses the relationship between corruption (Institutional Efficiency) and economic growth. The vital issue of endogeneity can be tackled in this study. To control for simultaneity bias and endogeneity, within a panel data framework I use 2SLS with random effect on corruption (institutional efficiency) which can be explained by geographical 
endowments and relate it to GDP per capita growth rates over the period of 1996-2013. My results indicate a strong causation between the exogenous component of corruption and economic development.

While corruption is affecting growth rate, economic growth is also affecting the corruption situation. (Daron Acemoglu et al., 2012; Beck \& Laeven, 2006; Easterly, William and Levine, 2003; Glaeser et al., 2004; Sala-i-Martin \& Subramanian, 2008) consider the endogenous relationship between corruption and economic growth. For example, the absence of corruption has a positive impact of economic growth and at the beginning stages transition period countries that managed to provide better corruption control has achieved better economic growth and less corruption, in the long run, compared to the pre-transition period (Beck \& Laeven, 2006). In my econometric methodology, I use the corruption score of the country from the Transparency International and GDP per capita of World Bank data by controlling for the variables that affect both the corruption and growth to avoid omitted variable bias. Finally, I use the weak instrument robust test to check the validity and shortcomings of the instruments used in my analysis.

This paper is related to two standards of literature. First, it relates to the vast literature on geographical effect on economic development. Second, this work is also linked to the literature on corruption (institutional development) and economic development. Empirical analysis of the relationship between institutional building and economic growth is becoming more and more feasible and desirable. My hypothesis is that corruption is the only factor that determines the quality of the institution. When policymaker has no chance for rents and corruption institution will be efficient in policy making and growth will prevail. To my knowledge, my paper is better comparing the other literature in that scene that. (1) I present a conceptual framework of corruption based on countries differences in endowments, historical and cultural factors. (2) Investigate the relationship between the exogenous components of corruption and economic development for a large number of samples countries. (3) I address the problem of endogeneity and use Instrument Variable (IV) approach more specifically; Two Stage Least Squares (2SLS) in a panel data framework. My analysis is basically an upgrade of the work done by many researchers such as (Easterly, William and Levine, 2003; Beck \& Laeven, 2006).

I would like to point out several limitations of my research. First, there determinants and consequences of corruption (institutional effectiveness) are broadly defined. I do not use another indicator that captures specific dimensions. Second, most of the instruments used in the analysis are fixed in nature. It's hard to determine the time-varying effect. Third, I only focus on corruption while controlling for historical and cultural factors.

The remainder of this paper is arranged as follows. The various literature is discussed in Section 2; the empirical model and data description are presented in Section 3; Section 4 the empirical results are presented in Section 5, and concluding remarks are made in Section 6.

\section{Diversified Hypothesis}

Numerous studies investigate the contribution of the institution on economic growth, but a 
few kinds of literature emphasize corruption. Beck and Laeven (2006) using cross-section data and the Instrument Variable (IV) approach on 24 transition countries showed that, dependence on natural resources and the historical experience of these countries during socialism as a major determinants of institution building during transition period, and also institution is important in explaining the variation in economic development and growth across transition countries especially during the first decade of the transition. Easterly and Levine (2003) also using the same IV method on cross-section data and the same measure of Institutions for 72 former colonies and showed that geographical endowments affect economic growth through their effect on the institution.

\subsection{Geographical Endowments Hypothesis}

Geographic differences play an important role in economic performers of the various societies and it forms a pattern that is widely recognized by the scholars especially in the recent economic times. Opposed by the methodical proofs of strong empirical regularities, for example, the per capita income of the countries near the equator lagging far behind that of their neighbours at more moderate latitudes, scholars wish to obtain knowledge of the procedure of economic development by analyzing these source of disparities in the endowment. From this concept, two schools of thoughts scholars emerged to analyze the discrepancies. One considers the direct effect of geographic conditions and that closely focus on the association of economic growth to geographies such as climate, disease environment, soil quality, or access to markets, and on the availability and productivity of labour, education, and protection of property rights and other factors of production. On the other hand, the other school of thoughts tried to find the indirect effect of this differences by looking at the effects of geography and factor endowments through the effect of the effectiveness of institutions involved in the process of economic growth. Both of this type of scholars view comes from the different school of thoughts, but in recent times it becomes a common practice of scholars to compare both the effects (D. Acemoglu et al., 2002; Easterly, William and Levine, 2003; Beck \& Laeven, 2006; Sala-i-Martin \& Subramanian, 2008).

First, scholars believed in the direct effect of geography such as area, latitude, rainfall on development. The list of scholars who have emphasized the importance of geographic endowments to economic development is long and distinguishable (Galbraith, 1951; Machiavelli, n.d. ; Montesquieu \& de Secondat, n.d.; Gallup \& Sachs, 2000; Limao, 2001). All of these scholars viewed geographical differences as a key determinant of work effort, productivity, and ultimately, the economic growth. Diamond and Ordunio (1997) considering the history of agriculture and productivity argued that ecological and geographical barriers can play in the evolution of human societies. Gennaioli et al. (2014) using a sample of 1,503 regions from 82 countries with instrumental variables approach, with lagged GDP serving as an instrument for current GDP conclude that regional growth and national growth is shaped by a factor such as a geography and human capital. Brunnschweiler (2008) using OLS and 2SLS regressions to examines the effects of natural resource abundance on economic growth considering the new measures of resource endowment and role of the institution, and conclude that there is a positive direct empirical relationship between natural resource abundance and economic growth. 
Second, other believed geography works through other factors such as institutions on growth. Engerman and Sokoloff (2002) comparing the North American countries with the South American claimed that geographical endowments alone can't explain growth without considering institutional factors such as the degree of democracy, the extent of rent-seeking, security in property rights, the inclination to work hard or be entrepreneurial, as well as culture and religion.

According to some empirical research related to the country size that there is the curse of natural resources - the observation that countries rich in natural resources tend to perform badly. Sachs and Warner (2001) argue that countries with great natural resources tend to grow more slowly than resource-poor countries and there is a little direct evidence that omitted geography or climate variables explain the curse. Land areas, especially accessible or arable land area, can give an indication of the potential or actual diversity of non-human natural resources (Downes, 1988). Porta et al. (1998) found that the larger governments tend to be the better-performing ones. Sachs and Warner (1995) in a large cross-country study found that economies abundant in natural resources have tended to grow slower than economies without substantial natural resources.

There have been several studies on the link between latitude and economic development. Montesquieu \& de Secondat, n.d. claimed that because of the heated climate in the north compared to the south is better for practising vices, virtues, sincerity and truthfulness. Porta et al. (1998) find that countries that are poor in nature, close to the equator, ethnolinguistically heterogeneous, uses French or Socialist laws, or have a high proportion of Catholics or Muslims exhibits inferior government performance. Brunnschweiler (2008) in a large cross-country study with OLS regression showed that there is an indirect effect of latitude on economic development through the channel of the institution. Easterly and Levine (2003) showed that there is a positive association between latitude and economic development and countries with higher absolute lauded tend to have higher levels of real per capita GDP. Gennaioli et al. (2014) showed that latitude and natural resource endowments influence growth rate in an expected way.

Ethnicity plays a major role in determining the quality of the institution and economic growth. Easterly and Levine (1997) in his research of African countries, showed that ethnic diversity helps explain cross-country differences in public policies and other economic indicators. It is because of this paper it becomes a common practice of the researchers to include fictionalization in growth analysis. Alesina et al. (2003) argued that ethnic fictionalization is closely correlated with GDP per capita and is higher in poorer countries that are close to the equator. This proves that ethnic fragmentation is a determinant of policy variables, the quality of government and eventually to growth.

Some arguments are that historical legal origin matters for development. The colonial experience is an important indicator in understanding the country's political institutions origins. In the past few decades, economists have produced a considerable number of research on legal origin suggesting that the historical origin of a country's laws is highly correlated with a broad range of its legal rules and regulations, as well as with economic 
outcomes (La Porta, Rafael and Lopez-de-Silanes, Florencio and Shleifer, 2008). Daron Acemoglu, Johnson, and Robinson (2012) argued that the mortality rate among the European settlers and the population density in the settled country determined their decision whether or not to settle in that colony. Porta et al. (1998); La Porta et al. (1999) claimed that the rule that protects investor will vary across the countries and based on its legal origin. For example, French legal origin countries generally intervene more in the economy (La Porta, Lopez-de-Silanes, \& Shleifer, 2002). Rostowski, Stacescu, and others (2006) argued that when we are construction growth model the legal origin should enter the regression through education. They also argued that when we are construction growth model the legal origin should enter the regression through education.

\subsection{Corruption Hypothesis}

In recent time, many economists have believed the idea that good economic institutions specifically those in the public sector, are instrumental to economic development. Some of the main characteristics of those institutions include limited government control, a relatively benign and corruption free bureaucratic and legal system that protects property rights and enforces contracts, and modest taxation and regulation. These characteristics of good governance have been seen in European countries and the developing countries over the last millennium as well as in the growth process across countries over the last 40 years. La Porta et al. (1999) argued that political theories focus on redistribution rather than efficiency, and hold that view that policies and institutions are shaped by those who are staying power to stay in power and to transfer resources to only themselves. According to political theories, government policies are inefficient not just because they are expensive to fix, but because their creators want them so. This put another light in the argument of political corruption.

The greatest obstacle to development is the corruption in the public sector (Kaufman, 1997). Because higher the corruption level the lowers the investment and economic growth (Mauro, 1995). Kaufmann, Kraay, and Zoido-Lobatón (1999) defined graft as "improper practices" and payments that are required to "get things done". Mauro (1995) used ethnolinguistic fractionalization of the population as an instrument for corruption for his analysis. The degree of corruption has a significant negative association with the efficiency of investment choices, (Swaleheen, 2007). It is also seen that corruption has a negative effect on productivity growth (Salinas \& Jiménez, 2007). High level of corruption also discourages foreign direct investment (Wei, 2000). However, some authors comment that corruption increases the overall efficiency of the economic system (Lui, 1985). Rose-Ackerman and Palifka (2016) stress that some issues, for example, tax evasion, violation of environmental rules, certification of unqualified people for public benefit, and grants of immunity to organized crime reduce efficiency. Danon (2011) express that corruption increases transaction costs, whereas the rise in corruption makes those costs more important, and thus lowers the overall efficiency of one economy. This kind of practice also gives bureaucrats an incentive to delay transactions in order to extract higher rent-seeking behaviour Rose-Ackerman and Palifka (2016). As we can imagine that corruption is doing a great deal of effect on the economy and lives of the general people anti-corruption steps should be taken to eradicate this. Corruption inheres in all social systems, feudalism, capitalism, socialism, and communism. It affects all 
classes of society; all state organizations, monarchies and Republics; all situations in war and peace; all age groups; both sexes and all times; ancient, medieval and modern (Alatas, 1990). Graeff and Svendsen (2013) conclude that corruption is a strong direct predictor of the lower level of economic development. Corruption might be a strong predictor of lower however, there is some argument that corruption is determined by economic growth. It is quite logical that the country those are poor and does not manage to provide the basic need of the citizen's corruption prevails and thus affect the economy. The low-income situations are tightly correlated to the high level of corruption (Sah, 1988). This suggestion is also supported by the findings of Graeff and Svendsen (2013) relation to EU countries. They also conclude that corruption is a strong direct predictor of the lower level of economic development.

Geographical endowments can explain corruption is a significant way. This can be seen the many empirical analysis. Engerman and Sokoloff (2002) comparing the North American and European countries with the South American claimed that geographical endowments alone can't explain growth without considering institutional factors such as legal origin, religion and rent-seeking behaviour. Beck and Laeven (2006) showed that dependence on natural resources and the historical experience of countries during socialism as a major determinants of institution building (corruption) during transition period, and also institution (corruption) is important in explaining the variation in economic development and growth across transition countries especially during the first decade of the transition. Arezki and Brückner (2011) using a panel of 30 oil-exporting countries during the period 1992 to 2005 showed that increase in oil rents significantly increases corruption.

Corruption is associated with the quality of the institutions and the functionality of the public sector, so the literature on corruption and economic results are closely related to the study of institutional integrity. (del Mar Salinas-Jiménez \& Salinas-Jiménez, 2007) Using 22 OECD countries using different corruption indicators showed that corruption negatively affects the efficiency level of the economy, suggesting that it not only affect the productivity of the economy but also the overall growth rate. Social interaction has a statistically significant positive effect on the corruption rate in China (Dong \& Torgler, 2012). In societies with a thick, extensive informal social network, the bribery-corruption relationship can be easily established and the risk of being reported is very low For example Asian countries like China, India, Bangladesh, Cambodia, Pakistan etc. North (1981) defined institutions as, "a set of rules, compliance procedures, and moral and ethical behavioural norms designed to constrain the behaviour of individuals in the interests of maximizing the wealth or utility of principals" (p. - 201-2012). When these moral and ethical behaviours are violated the society become unrest and thus the problem of corruption and other arises. Kaufmann, Kraay, and Zoido-Lobatón (1999) using a simple variant of unobserved components model illustrated aggregate governance indicators by constructing aggregate indicators of bureaucratic quality, rule of law, and graft provide a valuable real guidance to officials making reals laws and regulations. La Porta et al. (1999) on quality of government argue that both legal origin, distance from the equator and ethnolinguistic fractionalization explain the quality of government.

Social security plays an important role in determining the outcome of an economy. Good 
rules and regulation are matters of development. Legal protection of outside investors by corporate insiders limits the extent of expropriation of such investors and therefore supports financial development (La Porta, Lopez-de-Silanes, Shleifer, \& Vishny, 1997; Porta et al., 1998). The available studies of legal origin have shown that legal origin affects economic outcome through law and regulations. Caballero et al. (2013) found that the country which has strong rule of law managed to provide higher job security by the association of slower adjustment to shocks and lower productivity growth. In some cases, transplantation of legal and regulatory rules might itself become a serious case of inefficiency because as rules those are suitable for developed countries become a source of massive delay and corruption in the developing countries that follow them (La Porta, Rafael and Lopez-de-Silanes, Florencio and Shleifer, 2008).

Perceived wisdom argues that corruption is bad for income inequality. It is proven by the literature of (Ades \& Di Tella, 1997; Dincer \& Gunalp, 2008; Gupta, Davoodi, \& Alonso-Terme, 2002; Gyimah-Brempong \& de Gyimah-Brempong, 2006; Li, Xu, \& Zou, 2000) that there is a positive relationship between corruption and inequality: more corruption leads to more inequality. More corruption actually increases poverty by increasing the gap between the reach and poor which in turn increases inequality. But Dobson and Ramlogan-Dobson (2012) on their recent research on Latin America fined a trade-off between corruption and inequality and explains the finding with regard to the large informal sector in the region. Entry restriction and regulation determines the level of corruption. Djankov et al. (2002) examine the regulation to entry into the market on corruption and the size of the unofficial economy. La Porta, Rafael and Lopez-de-Silanes, Florencio and Shleifer (2008) showed that a number of steps to open a new business are negatively associated with corruption index. Ciccone and Papaioannou (2007) report countries which have fewer entry regulations tend to have more entry in the industry and this results in expanding global demand and technology shifts. Freund and Bolaky (2007) showed that trade openness has a positive impact of per capita income in cross-country analysis and this is only effective in countries which have low regulation of entry. Levy (2007) argued that corruption and the black market mechanisms emerged endogenously in Georgia because the Soviets did not allow free markets. Leeson and Sobel (2008) showed that bad weather can be a cause of corruption because disaster brings aid money and corruption prevails in those disaster-relief related cases.

Frequent government intervention is damaging for growth and corruption. Balachandrudu (2006) argued that the modernizing countries which lack effective political party; corruption is inversely related with political organization and corruption is encouraged by heavy reliance on government intervention in the economy or by the excessive bureaucratic overlay. Nasir (2011) in his paper suggests there is a linkage between institutional rigidity, manifested through high corruption, inefficient bureaucracy, inadequate protection for property rights, and political instability on the inflation rate. Al-Marhubi (2000) argues that there is a loss of government revenue because of corruption through tax evasion, underground activities and capital flights. Desai, Olofsgård, and Yousef (2005) using data on 120 countries over the period of 1960-2000, he suggests that the interaction between the political instability and 
inequality does give rise to inflationary pressure.

Many scholars have agreed on this matter that corruption leads to more corruption. Ali and Isse (2002) found that levels of corruption the present were strongly affected by previous levels. Corruption of one period is associated with the corruption of the previous period or on lower GDP per capita.

\section{Empirical Model}

\subsection{Endogeneity}

The correlation between the dependent variable, suspected endogenous variable, and instruments are reported in table 1. Although it shows a strong positive correlation between corruption and GDP per capita, the empirical results may suffer from two types of endogeneity. To address omitted variable bias, I first attempt to control for a standard set of variables that have been found by previous studies to affect both the corruption and economic development, such as legal origin, ethnic fractionalization and religion. The other possible endogeneity issue is reverse causality running from the economic development to the presence of corruption. In both cases, the coefficient estimates from the OLS regressions are biased and inconsistent. To emphasize these endogeneity issues, in my second strategy, I use the IV approach (Two Stage Least Squares) to alleviate any remaining endogeneity effect.

\subsection{Two-Stage Least Square}

To consider the possible issue of endogeneity between corruption and GDP per capita in the later section, I use the 2SLS estimation according to the following structure.

$$
\begin{aligned}
& \text { Second Stage :GDP } i t=\delta_{0}+\delta_{1} \text { CORR }_{i t}+\delta_{2} \text { CONTL }_{i t}+\psi_{i t} \\
& \text { First Stage }: \operatorname{CORR}_{i t}=\gamma_{0}+\gamma_{1} \text { ENDOW }_{i t}+\gamma_{2} \text { CONTL }_{i t}+v_{i t}
\end{aligned}
$$

Where, GDP $i t$ is the GDP per capita for country " $i$ " at time " $t$ ". CORR $i t$ is the corruption score of the country. ENDOW $i t$ is the geographic endowment variables such as logarithm of area, logarithm of latitude, landlocked and precipitation. $C O R R_{i t}$ is the set of included exogenous variable, this means that these variables will be included in the second stage of the regression namely; legal origin, ethnic, language and religion. In some of this regression, the $C O R R_{i t}$ variable will be omitted. $v_{i t}$ and $\psi_{i t}$ is the error terms of the first and the second-stage regressions respectively. When selecting a compatible estimation strategy for my study, there are issues need to be paid attention. First, GDP per capita may influence corruption. Thus, there is a possible two-way causality which needs to be tackled in my analysis which is shown in table 1. According to the Hausman test of endogeneity, corruption is correlated with the error term of the main equation. Thus ordinary least squares (OLS) estimates are inconsistent because it cannot tackle the reverse causation and the correlation with the error term of the main equation. Therefore I need to use a model which can tackle this endogeneity problem. Table 1 shows a strong positive correlation between the corruption and GDP per capita however correlation does not mean causality and there is reverse causality between these variables. Economic growth can cause lesser corruption. Beck and Laeven (2006) consider the endogenous relationship between the institution and economic 
growth and used IV estimation to solve for the endogeneity. To solve the issue of endogeneity between corruption and GDP per capita I use IV regression more specifically 2SLS (Two Stage Least Squares). Since I have one endogenous variable and more than two instruments the IV regression suitable for this analysis is the 2SLS. Moreover, my data also suffer from heteroscedasticity therefore with the help of the procedure I can control for it. 2SLS also easily caters for non-linear and interactions effects and I would like to prove that the correlation between these geographic endowments and the GDP per capita growth is indirect and casual. My approach is similar to the one used by (Beck \& Laeven, 2006; Easterly, William and Levine, 2003). More specifically, I use IV correlated to GDP per capita via corruption but no reverse causation between them to GDP per capita. The instruments used in my analysis are the logarithm of the area, the logarithm of latitude, landlocked and precipitation. Not only does the selection of instruments satisfy the relevance and exclusion criteria, but also those are not reversely correlated with the common factors causing both the corruption and GDP per capita. See also Section 4.3 of the main results for the details of the construction and qualification of these IVs. One of the drawbacks of the 2SLS is that it needs to logically work through the structure of the model to specify individual equations for all the relationships for the 2 SLS estimator. Since in the next sections I will use the various combinations of variables to specify the causal relationship between the dependent, endogenous and the exogenous variables with the control variables this problem is handled properly. Moreover, 2SLS estimator depends upon the choice of reference variables and the variables used in my analysis is widely used in the institution literature when it comes to the question of IV regression which is extensively seen in the work of (Beck, Thorsten, Asli Demirgüç-Kunt, 2003; Beck, Demirgüç-Kunt, \& Levine, 2003; Rodrik, Subramanian, \& Trebbi, 2004; Thorsten, Beck, Demirguc-kunt, \& Levine, 2005). Lastly, 2SLS is efficient in small sample size and in my sample, the number of observations is not too big and only around 3500 .

Table 1. Correlation Between the Dependent, Endogenous and Instrument variables

\begin{tabular}{|l|c|c|c|c|c|c|}
\hline Variables & GDP_pc & Corruption & Total Area & Latitude & Landlocked & Precipitation \\
\hline GDP_pc & 1.00 & & & & & \\
\hline Corruption & 0.81 & 1.00 & & & & \\
\hline Total Area & -0.24 & -0.24 & 1.00 & & & \\
\hline Latitude & 0.66 & 0.72 & 0.05 & 1.00 & & \\
\hline Landlocked & -0.29 & -0.16 & -0.01 & -0.11 & 1.00 & \\
\hline Precipitation & -0.15 & -0.19 & -0.14 & -0.52 & -0.10 & 1.00 \\
\hline
\end{tabular}

Table 1 shows that corruption is highly correlated with GDP per capita and the correlation is 0.81 . This correlation proves that these endowments might have causality effect the corruption index as well as to GDP per capita in various ways. Since most of this endowment are natural the causality might be stronger for most of the variables and for simplicity, I include these variables as exogenous. Of all the endowments the correlation of the latitude is highest, which is consistent with the hypothesis provided previously. I bring legal origin and other variables such as Ethnic, Language and Religions to examine the effect of former colonization on many regions in the world. It should be noted that correlation does not prove 
causality and many kinds of literature state that there is an existing revere causality between the two variables.

Note: I take the data for the logarithm of GDP per capita and the Corruption for the latest available year (2013). The labels are the country code for the corresponding countries. Since there is overlapping of the label, to make it readable I delete the overlapping label and make it a read. This does not affect the trend.

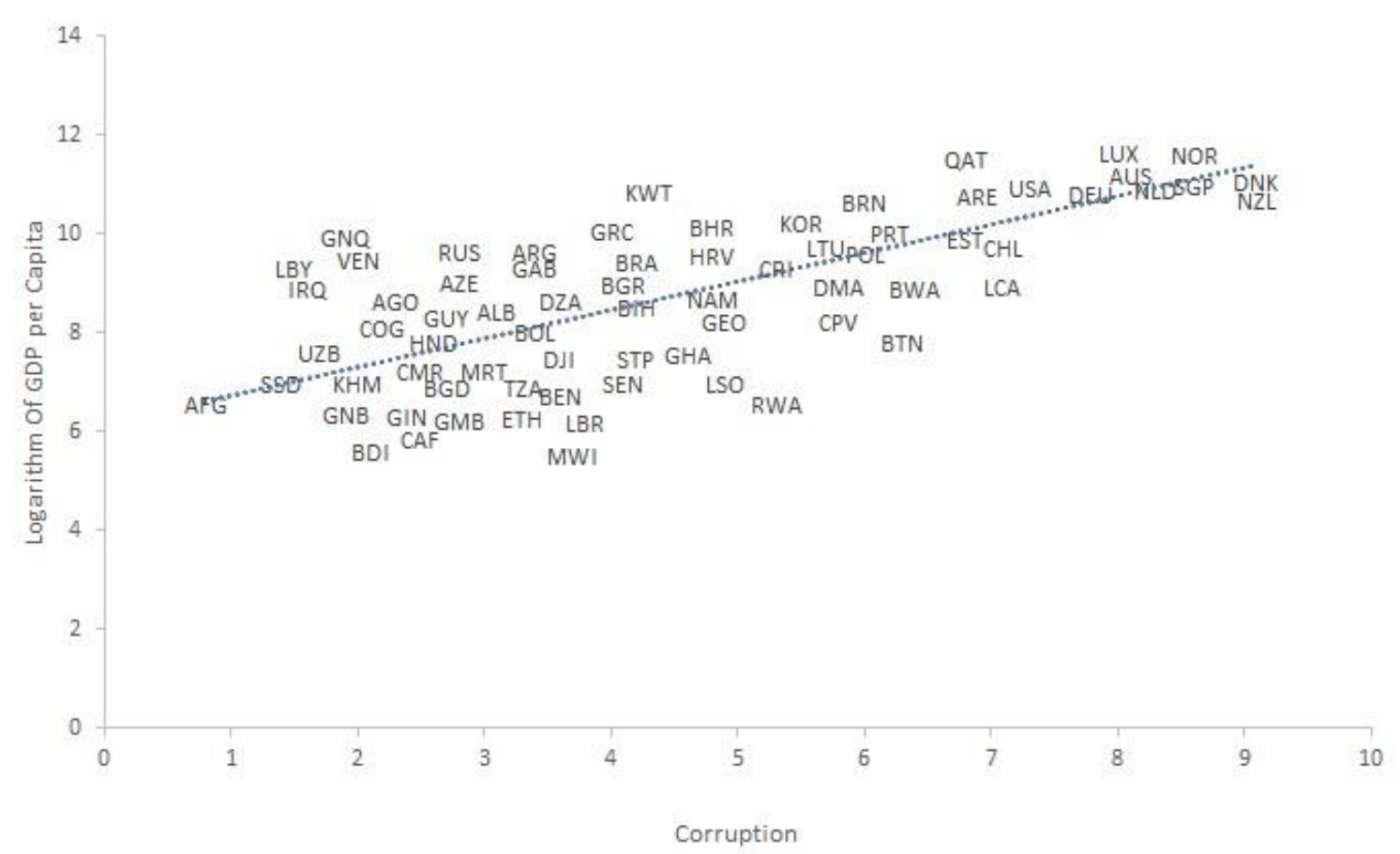

Figure 1. Correlation Between Corruption and GDP per capita

The horizontal axis shows the corruption score of TI and the vertical axis shows the logarithm of GDP per Capita of the World Bank. The legends on the figures are the short name of the countries.

Figure 1 shows that there is a positive correlation between the countries development and the lack of corruption. As we can see that countries like Norway, Denmark, Australia, Netherlands etc. which has higher GDP also have less corruption vice-versa. On the other hand countries like Afghanistan, Burundi, Guinea-Bissau, South Sudan etc. which has lower economic growth managed to scoreless in the corruption score (More corruption).

\subsection{Fixed vs Random Effect}

Since I am using the panel data set, there is a choice to be made whether to use Fixed effect or Random effect model. Fixed effect model uses dummy variables to extract the component of individual effects. This method uses differentiation to estimate the coefficients but this differentiating removes not only the individual effect of the model but also the time-invariant explanatory variables. In my analysis, the dependent variable GDP per capita varies over time but most of the explanatory variables such as total area, latitude and landlocked does not vary 
with time. The random effect model does not use any dummy variables like the fixed effect model. As a matter of fact, it assumes that the individual effect of the model is indeed a random variable. The random effects model has a large advantage over the fixed effect model in that manner that it has so many fewer parameters to estimate than the fixed effects model. Hausman test can is used to choose between the fixed and random effect specifications. It has the null hypothesis is that the individual effect is uncorrelated with any of the explanatory variables. Since according to the Hausman test and the structure of the explanatory variables are not suitable for the fixed effect model, the instrumental variable of the random effect is used in the analysis of the paper.

\section{Data, Variables, and Summary Statistics}

\subsection{Data and Sample}

In order to prove the theories concerning the extensive mechanism by which geographic and historical endowments such as country area, distance from the equator, landlocked or precipitation influence the economic development, it is important to calculate the underlying geographic endowments and indicators of the curse of corruption through which the two factors might affect the output of the economy. Table 2 showed the summary statistics of the variables used in my analysis. In this section of the paper, I will derive and define the variables that would be extensively used for my explanation and the model. Section 5 will provide the regression result.

In this paper, I tried to get as many data as possible to analyze the cross-country variation in corruption and GDP per capita analysis. I included a panel data for 192 countries over the year 1996 to 2014 in the regression to analyze the effects. Some countries are rejected from your database because of the unavailability of the two most important data on corruption and GDP. The reason behind taking data from 1996 is that my main variable corruption data from the TI (Transparency International) is only available form 1995 onward but in that time only a few countries have been included in the data. A more detailed description of the source of data and the measurement is shown next subsections. All the data of this analysis comes from (Teorell et al., 2015). The institute conducts research on the causes, consequences and nature of Good Governance and the Quality of Government (QoG) - that is, trustworthy, reliable, impartial, uncorrupted, and competent government institutions. One aim of the QoG Institute is to make comparative data on QoG and its correlates publicly available. To accomplish this, they have compiled several data sets that draw on a number of freely available data sources, including aggregated individual-level data.

\subsection{Descriptive Statistics}

The average corruption score is 4.24 which indicates that corruption exists in most of the countries and affecting the lives of the people as well as the economy. The minimum value of CPI is 0.4 which is obtained by Bangladesh in 2001. The minimum value for the area is 0.69 , indicating the smallest country in my sample is Monaco. On the other hand, the maximum value is 16.61. Russian Federation is the largest country in my sample. For latitude Congo is the country that is lied to the equator that's why it has the value of 0 . On the other hand, the 
maximum value is 0.72 . Finland lies to that latitude. It should be noted that the precipitation is collected from three different sources and compiled into one variable because of the unavailability of data. To get the combined precipitation data I take the value form Mitchell et al. (2003) from the year 1996 to 2000 which is cubic meters. After that, I converted the United National's data into cubic meters and fill it as available. Then I get the World Bank data from the year 2000 to 2014 whenever available. Since the data of the World Bank is the long-term average precipitation I take it the least. If there was overlapping data the prioritize by Mitchell then United Nations then World Bank.

Table 2. Summary Statistics

\begin{tabular}{|l|c|c|c|c|c|}
\hline Variable & Obs & Mean & Std. Dev. & Min & Max \\
\hline Corruption & 2355 & 4.24 & 2.20 & 0.40 & 10.00 \\
\hline Total Area & 3205 & 11.29 & 2.74 & 0.69 & 16.61 \\
\hline Latitude & 3417 & 0.29 & 0.19 & 0.00 & 0.72 \\
\hline Landlocked & 3648 & 0.22 & 0.41 & 0.00 & 1.00 \\
\hline Precipitation & 1853 & 1.16 & 0.81 & 0.00 & 4.38 \\
\hline GDP_pc70 & 2280 & 6.11 & 1.21 & 4.07 & 9.43 \\
\hline Legal Origin & 3455 & 2.01 & 0.95 & 1.00 & 5.00 \\
\hline Ethnic & 3154 & 0.44 & 0.26 & 0.00 & 0.93 \\
\hline Language & 3036 & 0.39 & 0.28 & 0.00 & 0.92 \\
\hline Religion & 3189 & 0.44 & 0.23 & 0.00 & 0.86 \\
\hline
\end{tabular}

Note Data source: World Development Indicator (WorldBank, 2016), Transparency International (TransparencyInternational, 2015), and Quality of Government (Teorell et al., 2015), constructed by the authors. Refer to Appendix B for variable definition and construction.

\section{Main Results}

This part of the paper answer four questions is being asked; first, do these endowments discussed previously explains the cross-country variation in economic development? Second, do these endowments explain the cross-country variation in the corruption index? If these endowment does not explain the cross-country variation in GDP per capita then the geography endowment hypothesis is not valid. If these endowments do not explain the cross-country variation in corruption index then there is no validity of corruption hypothesis. From the regression results of the first two questions, it is seen that endowments do manage to explain cross-country variations in economic development as well as the corruption index (direct effect). Now the research can be extended furthermore and two more questions are being asked. Third, do these endowments explain the cross-country variation in economic development through their ability to explain cross-country differences in corruption? If it doesn't it proves the indirect effect of corruption hypothesis and geographical endowment hypothesis is not valid. However, if it does it proves this paper and proves the geographical endowment hypothesis, and conclude that endowments explain the cross-country variation in economic development through their ability to explain cross-country difference in corruption. Fourth and final question, after considering that endowments explain cross-country variation in economic development through corruption, does policy managed to explain the 
cross-country variation in growth. These regression procedure and intuition is taken from the (Easterly and Levine, 2003; Beck and Laeven, 2006; Sala-i Martin and Subramanian, 2008).

\subsection{Economic Development and Endowments}

To answer the first question I will use a linear regression model for panel data. I will use a simple OLS on my panel data. My focus is to show the relationship between the GDP per capita and the endowments. In this case, I omit the problem of heteroskedasticity or autocorrelation. Specifically, I will use the logarithm of GDP per capita as the dependent variable and for independent variable each endowment variable at a time, then in groups and lastly together with the control variable.

$$
G D P_{i t}=\alpha_{0}+\alpha_{1} E_{N D O W}+\alpha_{2} \text { CONTL }_{i t}+\varepsilon_{i t}
$$

Table 3 represents the OLS regression of the geographic endowments and control variables to the logarithm of GDP per capita. The data presents the linear regression of the logarithm of GDP per capita on the various endowments indicators such as total area, latitude, landlocked and precipitation. Moreover, I also try to find the relationship between the logarithm of GDP per capita and the control variables i.e. Legal origin, entheogenic diversity, language and religious variable. I take one variable at a time and then run with the control variables and lastly in groups with and without the control variables. The reason behind including this control variables are to access the independent relationship between the endowments and the level of economic development. For example, in regression 1 in table 3 I only use logarithm of the area to logarithm of GDP per capita. In regression 2 I add the control variables with this endowment. I do this with all the endowments at a time, and then in groups, individually and with control variables.

The OLS regression of logarithm of total area, latitude, landlocked and precipitation are all individually significant at $1 \%$ with the logarithm of GDP per capita even when I include the control variables. Small country area, far away from the equator, open access to the sea and fewer precipitation countries tend to have more logarithm of GDP per capita when I am controlling for other variables such as legal origin, ethnicity, religion and linguistic fractionalization. Language is significant at $1 \%$ in most of all the equations, and ethnic, legal origin and religion are not significant in many of the cases. Since my goal is to show the relation between the endowments and the GDP per capita I will not consider this insignificance.

The overall $\mathrm{R}^{2}$ gets higher as I include more and more variables. This is actually a limitation of $\mathrm{R}^{2}$. When I include only the endowment variables the overall $\mathrm{R}^{2}$ is $44 \%$. And when all the variables are included in the regression the $\mathrm{R}^{2}$ is $49 \%$. All the variables explain $49 \%$ variation of GDP per capita. Latitude individually explains GDP more than any other endowment variables. It can single-handedly explain $27 \%$ variation in GDP per capita. 


\section{Macrothink}

Business and Economic Research

ISSN 2162-4860

Table 3. OLS on GDP per capita as the dependent variable

\begin{tabular}{|c|c|c|c|c|c|c|c|c|c|c|c|c|c|c|}
\hline & OLS & OLS & OLS & OLS & OLS & OLS & OLS & OLS & OLS & OLS & OLS & OLS & OLS & OLS \\
\hline Models & 1 & 2 & 3 & 4 & 5 & 6 & 7 & 8 & 9 & 10 & 11 & 12 & 13 & 14 \\
\hline \multirow[t]{2}{*}{ Total Area } & $-0.15^{* * *} *$ & $-0.15 * * *$ & & & & & & & $-0.20 * * *$ & $-0.17^{* * *}$ & $-0.19^{* * *}$ & $-0.18^{* * *}$ & $-0.21 * * *$ & -0.20 *** \\
\hline & $(0.041)$ & $(0.043)$ & & & & & & & $(0.037)$ & $(0.039)$ & $(0.033)$ & $(0.037)$ & $(0.034)$ & $(0.037)$ \\
\hline \multirow[t]{2}{*}{ Latitude } & & & $4.44 * * *$ & $4.31 * * *$ & & & & & $4.70^{* * * *}$ & $4.43^{* * * *}$ & $5.17 * * *$ & $4.86^{* * *}$ & $4.95^{* * *}$ & $4.46^{* * * *}$ \\
\hline & & & $(0.525)$ & $(0.688)$ & & & & & $(0.497)$ & $(0.654)$ & $(0.461)$ & $(0.620)$ & $(0.472)$ & $(0.638)$ \\
\hline \multirow[t]{2}{*}{ Landlocked } & & & & & $-0.83 * * *$ & $-0.76 * * *$ & & & & & $-1.25 * * *$ & $-1.05^{* * *}$ & $-1.33 * * *$ & $-1.11 * * *$ \\
\hline & & & & & $(0.267)$ & $(0.266)$ & & & & & $(0.212)$ & $(0.220)$ & $(0.214)$ & $(0.222)$ \\
\hline \multirow[t]{2}{*}{ Precipitation } & & & & & & & $-0.19 * * *$ & $-0.19 * * *$ & & & & & $-0.14 * * *$ & $-0.16^{* * * *}$ \\
\hline & & & & & & & $(0.042)$ & $(0.045)$ & & & & & $(0.043)$ & $(0.045)$ \\
\hline \multirow[t]{2}{*}{ Legal Origin } & & $0.28 * *$ & & $-0.24 *$ & & $0.29 * *$ & & 0.16 & & -0.19 & & -0.13 & & -0.14 \\
\hline & & $(0.117)$ & & $(0.130)$ & & $(0.119)$ & & $(0.123)$ & & $(0.124)$ & & $(0.117)$ & & $(0.118)$ \\
\hline \multirow[t]{2}{*}{ Ethnic } & & $\begin{array}{l}-0.89 \\
\end{array}$ & & -0.24 & & $-1.30 * *$ & & $-1.36 * *$ & & 0.17 & & 0.22 & & 0.00 \\
\hline & & $(0.595)$ & & $(0.569)$ & & $(0.590)$ & & $(0.621)$ & & $(0.548)$ & & $(0.515)$ & & $(0.524)$ \\
\hline \multirow[t]{2}{*}{ Language } & & $-1.69 * * *$ & & $-1.84 * * *$ & & $-1.39 * *$ & & $-1.79 * * *$ & & $-1.87 * * *$ & & $-1.48 * * *$ & & $-1.53 * * *$ \\
\hline & & $(0.545)$ & & $(0.506)$ & & $(0.558)$ & & $(0.575)$ & & $(0.480)$ & & $(0.458)$ & & $(0.464)$ \\
\hline \multirow[t]{2}{*}{ Religion } & & 0.22 & & 0.28 & & 0.32 & & 0.46 & & 0.17 & & 0.21 & & 0.37 \\
\hline & & $(0.475)$ & & $(0.441)$ & & $(0.508)$ & & $(0.503)$ & & $(0.419)$ & & $(0.393)$ & & $(0.400)$ \\
\hline F-Stat Walt-test & 0.0002 & 0.0000 & 0.0000 & 0.0000 & 0.0019 & 0.0000 & 0.0000 & 0.0000 & 0.0000 & 0.0000 & 0.0000 & 0.0000 & 0.0000 & 0.0000 \\
\hline \multicolumn{15}{|l|}{ R-Square } \\
\hline Within & 0.0021 & 0.0019 & 0.0000 & 0.0000 & 0.0000 & 0.0000 & 0.0122 & 0.0117 & 0.0021 & 0.0019 & 0.0021 & 0.0019 & 0.0117 & 0.012 \\
\hline Between & 0.0688 & 0.3003 & 0.2892 & 0.3996 & 0.0485 & 0.2878 & 0.0052 & 0.2633 & 0.3847 & 0.4642 & 0.4879 & 0.5313 & 0.4792 & 0.5313 \\
\hline Overall & 0.0587 & 0.2798 & 0.265 & 0.3726 & 0.0518 & 0.2674 & 0.0069 & 0.2192 & 0.3527 & 0.4296 & 0.4511 & 0.4934 & 0.4423 & 0.4897 \\
\hline Observations & 3117 & 2804 & 3310 & 2795 & 3509 & 2812 & 1800 & 1650 & 2970 & 2787 & 2970 & 2787 & 1728 & 1637 \\
\hline
\end{tabular}

The dependent variable is the logarithm of GDP per capita. In this panel regressions, OLS is being used. The sample size is of 190 countries. The Standard error in parenthesis and *, $* *$ and $* * *$ indicates significance at $10 \%, 5 \%$ and $1 \%$ respectively. The constant term is omitted in the table. The total area is the logarithm of the sum of all land and water areas delimited by international boundaries and/or coastlines is the logarithm of the county size or area. Latitude is the absolute value of each country's latitude. landlocked is the dummy whether the country has coastal access. Precipitation is any form of water that comes as rainfall or snow. Legal Origin legal traditions to giving different categories such as British common law, French civil law, German civil law, Scandinavian law, and socialist law. It is a composite variable. Ethnic is the probability that two randomly selected individuals are from a population belonged to different groups. Language is the number of the language spoken in the country and this language index given by Alesina et al. (2003). Religion identifies the percentage of the population of each country that belonged to the three most widely spread religions in the world. The numbers are in percentage (scale from 0 to 100). The three religions identified here are (1) Roman Catholic; (2) Protestant; and (3) Muslim. The residual is called "other Religions". 
As we can see the coefficient of legal origin in unambiguous and significant with the logarithm of the area, landlocked and latitude but insignificant with precipitation. And finally, when I include all the variables some control variables is not significant at all, especially in the case of legal origin, linguistic diversity and religion. This indicates that when there is omitted variables bias, the legal origin along with language and logarithm of the area managed to explain the variation in the logarithm of GDP per capita. This, in turn, means Scandinavian legal origin with less linguistic fractionalization and fewer country areas are significantly related with the logarithm of GDP per capita. This is shown in table 3 regression 2. On the other hand, regression 4 says the different story, not being Scandinavian legal origin, less linguistic fractionalization and more to the north countries are more developed. The regression results from above are clearly indicating that the geographic endowments can explain the cross-country variation in economic development. Each of the four endowment indicators included in the model, total area, latitude, landlocked and precipitation all significantly manages to explain the differences in the logarithm of GDP per capita. When the control variables, legal origin, ethnic diversity and religion are included in the regression the results stays the same. Focusing on the sign of the endowments it seems that their sign stays the same as the theory. Specifically, smaller land area, higher latitude, open access to the sea and moderate precipitation lead to higher economic development. When the exogenous control variables are included the only language is statistically significant in most of the cases, however legal origin, ethnic and religion is not significant in many cases, but this doesn't affect the intuition trying to be explained in this paper.

\subsection{Corruption and Endowments}

In this part, I try to provide evidence on how the endowments explain corruption. I use the same strategy as before only use corruption index as the dependent variable. The strategy is to use one independent variable at a time, then as a set, and with control variables. I use the simple OLS in the following form,

$$
\operatorname{CORR}_{i t}=\beta_{0}+\beta_{1} \text { ENDOW }_{i t}+\beta_{2} \operatorname{CONTL}_{i t}+\vartheta_{i t}
$$

The OLS regression with random effect explains that the logarithm of country area is significant at $10 \%$ with corruption perception index in all of the regressions in the model. The sign of logarithm of total area in negative in all the regressions. Which is consistent with the theory and indicates that the larger the country area the higher the corruption.

The latitude defines the corruption more than any other variable in my models. Latitude individually explains $28 \%$ variation in corruption. The coefficient of latitude is varied high and significant at $1 \%$ in all the regressions and even when I include the control variables. The farther we away from the equator the better the corruption score. This is consistent with the theory provided with the literature. Latitude determines the characteristics of a country. Weather, climate, rainfall, temperature, soil quality etc. all are determined by latitude. In all the regression landlocked is statistically significant with corruption. The coefficients are all 5\% statistically significant in all the regressions. 


\section{Macrothink}

Business and Economic Research

ISSN 2162-4860

Table 4. OLS on Corruption as the dependent variable

2019, Vol. 9, No. 1

\begin{tabular}{|c|c|c|c|c|c|c|c|c|c|c|c|c|c|c|}
\hline & OLS & OLS & OLS & OLS & OLS & OLS & OLS & OLS & OLS & OLS & OLS & OLS & OLS & OLS \\
\hline Models & 1 & 2 & 3 & 4 & 5 & 6 & 7 & 8 & 9 & 10 & 11 & 12 & 13 & 14 \\
\hline \multirow[t]{2}{*}{ Total Area } & $-0.16^{* *}$ & $-0.13^{*}$ & & & & & & & $-0.23^{* * * *}$ & $-0.18^{* * * *}$ & $-0.22 * * *$ & $-0.19 * * *$ & $-0.24 * * *$ & $-0.22 * * *$ \\
\hline & $(0.066)$ & $(0.076)$ & & & & & & & $(0.059)$ & $(0.069)$ & $(0.058)$ & $(0.067)$ & $(0.061)$ & $(0.069)$ \\
\hline \multirow[t]{2}{*}{ Latitude } & & & $5.36^{* * * *}$ & $5.49 * * *$ & & & & & $5.77 * * *$ & $5.84 * * *$ & $6.10^{* * * *}$ & $6.25^{* * * *}$ & $6.04 * * *$ & $6.01 * * *$ \\
\hline & & & $(0.717)$ & $(0.983)$ & & & & & $(0.699)$ & $(0.974)$ & $(0.685)$ & $(0.956)$ & $(0.703)$ & $(0.984)$ \\
\hline \multirow[t]{2}{*}{ Landlocked } & & & & & $-0.72 * *$ & $-0.75 * *$ & & & & & $-1.08 * * *$ & $-1.06 * * *$ & $-1.10 * * *$ & $-1.10 * * *$ \\
\hline & & & & & $(0.365)$ & $(0.378)$ & & & & & $(0.317)$ & $(0.337)$ & $(0.322)$ & $(0.338)$ \\
\hline \multirow[t]{2}{*}{ Precipitation } & & & & & & & -0.07 & -0.07 & & & & & -0.02 & -0.03 \\
\hline & & & & & & & $(0.061)$ & $(.062)$ & & & & & $(0.061)$ & $(0.061)$ \\
\hline \multirow[t]{2}{*}{ Legal Origin } & & 0.27 & & $-0.33^{*}$ & & $0.28 *$ & & 0.10 & & -0.29 & & -0.24 & & $-0.31 *$ \\
\hline & & $(0.170)$ & & $(0.183)$ & & $(0.170)$ & & $(0.176)$ & & $(0.180)$ & & $(0.176)$ & & $(0.177)$ \\
\hline \multirow[t]{2}{*}{ Ethnic } & & $-2.42 * * *$ & & $-1.39 *$ & & $-2.85 * * *$ & & $-3.38 * * *$ & & -0.82 & & -0.81 & & $-1.39 *$ \\
\hline & & $(0.839)$ & & $(0.790)$ & & $(0.813)$ & & $(0.871)$ & & $(0.805)$ & & $(0.783)$ & & $(0.818)$ \\
\hline \multirow[t]{2}{*}{ Language } & & -0.54 & & -0.65 & & -0.23 & & -0.41 & & -0.68 & & -0.26 & & -0.09 \\
\hline & & $(0.758)$ & & $(0.698)$ & & $(0.769)$ & & $(0.787)$ & & $(0.686)$ & & $(0.679)$ & & $(0.695)$ \\
\hline \multirow[t]{2}{*}{ Religion } & & 1.02 & & $1.05^{*}$ & & $1.16^{*}$ & & $1.34 *$ & & 0.90 & & 0.95 & & $1.12 *$ \\
\hline & & $(0.676)$ & & $(0.620)$ & & $(0.671)$ & & $(0.695)$ & & $(0.611)$ & & $(0.595)$ & & $(0.603)$ \\
\hline F-Stat Walt-test & 0.0133 & 0.0000 & 0.0000 & 0.0000 & 0.0489 & 0.0000 & 0.2492 & 0.0000 & 0.0000 & 0.0000 & 0.0000 & 0.0000 & 0.0000 & 0.0000 \\
\hline \multicolumn{15}{|l|}{ R-square } \\
\hline Within & 0.0005 & 0.0005 & 0.0000 & 0.0000 & 0.0000 & 0.0000 & 0.0012 & 0.0012 & 0.0005 & 0.0005 & 0.0005 & 0.0005 & 0.001 & 0.0011 \\
\hline Between & 0.0328 & 0.197 & 0.2458 & 0.3179 & 0.0211 & 0.2024 & 0.0010 & 0.2035 & 0.3085 & 0.3475 & 0.3526 & 0.3867 & 0.3516 & 0.4016 \\
\hline Overall & 0.0299 & 0.2376 & 0.2781 & 0.3448 & 0.0211 & 0.2398 & 0.0015 & 0.2152 & 0.3196 & 0.3655 & 0.3644 & 0.4033 & 0.3557 & 0.3948 \\
\hline Observations & 2170 & 2047 & 2297 & 2054 & 2355 & 2054 & 1153 & 1110 & 2127 & 2047 & 2127 & 2047 & 1133 & 1103 \\
\hline
\end{tabular}

The dependent variable is the Corruption index from Transparency International. In this panel regressions with OLS estimation is being used. The sample size is of 190 countries. The standard error in parenthesis and $* * *$ and $* * *$ indicates significance at $10 \%, 5 \%$ and $1 \%$ respectively for each variable are also being reported in the table. The constant term is omitted in the table. The total area is the logarithm of the sum of all land and water areas delimited by international boundaries and/or coastlines is the logarithm of the county size or area. Latitude is the absolute value of each county's latitude. landlocked is the dummy whether the country has coastal access. Precipitation any form of water that comes as rainfall or snow. Legal Origin legal traditions to giving different categories such as British common law, French civil law, German civil law, Scandinavian law, and socialist law. It is a composite variable. Ethnic is the probability that two randomly selected individuals are from a population belonged to different groups. Language is the number of the language spoken in the country and this language index given by Alesina et al. (2003). Religion identifies the percentage of the population of each country that belonged to the three most widely spread religions in the world. The numbers are in percentage (scale from 0 to 100). The three religions identified here are (1) Roman Catholic; (2) Protestant; and (3) Muslim. The residual is called "other Religions". 
A country's geographical location has a significant effect on its corruption, especially the access to the sea. Access to sea enables a country to keep in touch with its trading partners. Lack of access to sea does not enable the country to historically developed better institution like those of in Europe. The value of the coefficient is negative indicates this causal relationship. Precipitation is the source of natural water in a country. A decent amount of precipitation can boost the GDP. Too much precipitation can damage the economy by natural disaster and thus corruption persist in the presence of disaster aid. In the above two tables, precipitation is insignificant with the corruption index. The value of this coefficient is very low in all the regressions.

I include all the endowments individually and together with the control variables they stay significant at $10 \%$ level; Except for the precipitation. When in table 4 regression 14, all the endowments are regressed together with the control variables only area, latitude and landlocked stays significant and of the control variable legal origin, ethnicity and religion stays significant. The legal origin is significant in some regressions but the sign is different. Ethnic fractionalization is significant in most of the regression and the sign is consistent. This indicates more ethnically diversified countries tend to have worse at corruption. This is consistent with the theory, that ethnicity can affect corruption. People do more favour within their ethnic group then the outsiders. The coefficient of ethnicity is very high in all the regression. Language is not significant in any of the regression. This indicates when it comes to corruption linguistic fractionalization does not matter. Religion is significant in many regressions, especially in the final regression where I include all the variables together. In all the religions, it says the bad effect of corruption and prevents individual to be corrupt. Thus, religious countries tend to have better corruption. Small country area, away from the equator countries and have access to sea countries tends to have less corruption when I am controlling for other variables such as legal origin, ethnicity, religion and linguistic fractionalization. The value of $\mathrm{R}^{2}$ is 0.39 (overall). A country precipitation can only explain 39\% variations in corruption perception index when I control for other variables.

\subsection{Does Endowments Explain Economic Development Through Corruption?}

In so far the regressions managed to explain that the endowments affect both economic development and corruption. Those findings are valid in accordance with the hypothesis stated in the previous section, which means that endowments do manage to explain corruption and therefore affect GDP per capita. Findings are also consistent with the corruption hypothesis, which explains that endowments do affect corruption through the development of the country, participation and management, which in turn happens to affect economic development. In this segment, the analysis of differentiating the two effects are discussed and the hypothesis is explained more elaborately.

\subsubsection{Econometric Specification and Models}

Here it will be proven that how the benefits of endowments are being offset by higher corruption level (lower CPI score) and damaging the economic growth. Since there is a two-way causality between the GDP per capita and Corruption. Obviously, some endogeneity 
problem that's why IV regression is called for. I use the heteroskedasticity consistent, robust and clustering on Country Two-Stage Least Squares technique (2SLS) with random effect. The IV (Instrumental Variable) technique is used for the analysis is the Two-Stage Least-Squares (2SLS) in the following expression:

$$
\begin{aligned}
& \text { Second Stage :GDP } i t=\delta_{0}+\delta_{1} \text { CORR }_{i t}+\delta_{2} \text { CONTL }_{i t}+\psi_{i t} \\
& \text { First Stage : } \text { CORR }_{i t}=\gamma_{0}+\gamma_{1} \text { ENDOW }_{i t}+\gamma_{2} \text { CONTL }_{i t}+v_{i t}
\end{aligned}
$$

Table 5. Endowments, Corruption and GDP per capita: Two Stage Least Squares (2SLS)

\begin{tabular}{|l|l|l|l|l|l|l|}
\hline & 2SLS RE & 2SLS RE & 2SLS RE & 2SLS RE & 2SLS RE & 2SLS RE \\
\hline Models & 1 & 2 & 3 & 4 & 5 & 6 \\
\hline Corruption & $0.75^{* * *}$ & $0.68^{* * *}$ & $0.80^{* * *}$ & $0.73^{* * *}$ & $0.74^{* * *}$ & $0.67 * * *$ \\
\hline Total Area & $(0.063)$ & $(0.078)$ & $(0.067)$ & $(0.075)$ & $(0.064)$ & $(0.069)$ \\
\hline & $-0.22^{* * *}$ & $-0.18^{* *}$ & $-0.22^{* * *}$ & $-0.18^{* *}$ & $-0.20^{* *}$ & $-0.19^{* *}$ \\
\hline Latitude & $(0.067)$ & $(0.083)$ & $(0.066)$ & $(0.083)$ & $(0.080)$ & $(0.089)$ \\
\hline & $5.84^{* * *}$ & $5.77^{* * *}$ & $6.19^{* * *}$ & $6.19^{* * *}$ & $6.97^{* * *}$ & $7.03^{* * *}$ \\
\hline Landlocked & $(0.787)$ & $(1.001)$ & $(0.761)$ & $(0.977)$ & $(0.882)$ & $(1.269)$ \\
\hline & & & $-1.14^{* * *}$ & $-1.10^{* * *}$ & $-1.15^{* * *}$ & $-1.16^{* * *}$ \\
\hline Precipitation & & & $(0.319)$ & $(0.325)$ & $(0.348)$ & $(0.373)$ \\
\hline & & & & & $0.38^{* * *}$ & $0.40^{* *}$ \\
\hline Legal Origin & & & & & $(0.138)$ & $(0.168)$ \\
\hline & & 0.00 & & -0.01 & & 0.01 \\
\hline Ethnic & & $(0.083)$ & & $(0.089)$ & & $(0.089)$ \\
\hline & & 0.47 & & 0.61 & & 0.65 \\
\hline Language & & $-1.527)$ & & $(0.532)$ & & $(0.546)$ \\
\hline & & $(0.395)$ & & $-1.16^{* * *}$ & & $-1.23 * * *$ \\
\hline Religion & & -0.41 & & -0.47 & & $(0.379)$ \\
\hline & & $(0.308)$ & & $(0.321)$ & & -0.47 \\
\hline F-Stat First Stage (Prob) & 0.0000 & 0.0000 & 0.0000 & 0.0000 & 0.0000 & 0.0000 \\
\hline Hansen J Statistic & 0.8477 & 0.7603 & 0.1269 & 0.3439 & 0.1642 & 0.2604 \\
\hline Endogeneity Test & 0.0000 & 0.0000 & 0.0000 & 0.0000 & 0.0000 & 0.0000 \\
\hline $\begin{array}{l}\text { Weak } \\
\text { Instrument test }\end{array}$ & Reject & Reject & Reject & Reject & Reject & Reject \\
\hline Cragg-Donald Wald & 219.29 & 126.527 & 165.127 & 104.042 & 144.026 & 84.193 \\
\hline Kleibergen-Paap & 37.42 & 20.749 & 31.426 & 18.457 & 22.228 & 12.481 \\
\hline Stock-Yogo & 19.93 & 19.93 & 22.3 & 22.3 & 24.58 & 24.58 \\
\hline Observation & 2098 & 2018 & 2098 & 2018 & 1121 & 1091 \\
\hline
\end{tabular}

The dependent variable is the logarithm of GDP per capita. In these panel regressions Two-Stage Least Squares with random effect, (2SLS) estimation is being used. The sample size is of 190 countries. The heteroskedasticity consistent robust and clustered by a country standard error in parenthesis and $*, * *$ and $* * *$ indicates significance at $10 \%, 5 \%$ and $1 \%$ respectively. The constant term is omitted in the table. The endogenous variable is the CPI (corruption), a score of Transparency International. The score lies between 0 and 10 . The instrument variables those have been excluded from the second stage regression are as following total area, latitude, landlocked and precipitation. The total area is the logarithm of the sum of all land and water areas delimited by international boundaries and/or coastlines is the logarithm of the county size or area. Latitude is the absolute value of each county's latitude. Landlocked is the country that does not have a coastal area. Precipitation is the natural waterfall to land in the form of snow or rain. The exogenous control variables that are included in the second stage of the regression are as following; Legal Origin legal traditions into giving different categories such as British common law, French civil law, German civil law, Scandinavian law, and socialist law. It is a composite variable. Ethnic is the probability that two randomly selected individuals are from a population belonged to different groups. Language is the number of the language spoken in the country and 
this language index given by Alesina et al. (2003). Religion identifies the percentage of the population of each country that belonged to the three most widely spread religions in the world. The numbers are in percentage (scale from 0 to 100). The three religions identified here are (1) Roman Catholic; (2) Protestant; and (3) Muslim. The residual is called "other Religions". Hansen J. Statistics is the test for overidentification restrictions where the Null hypothesis: instruments are valid. Endogeneity Test (Prob): the Null hypothesis of exogenous variables. Weak instruments test: Null hypothesis instruments are weak.

Here, $\operatorname{CORR}_{i t}$ is the set of the included exogenous variable for the country " $i$ " at a time " $t$ ", this means that these variables will be included in the second stage of the regression namely; legal origin, ethnic, language and religion. In some of this regression, the $C O R R_{i t}$ variable will be omitted. $v_{i t}$ and $\psi_{i t}$ are the error terms of the first and the second-stage regressions respectively. The endowments will be excluded from the second-stage regression moreover, they are considered as the excluded exogenous variables and in this model as they are used as instrumental variables to extract the exogenous component of the corruption index. In this model, the number of this instruments variable varies is from 2 to maximum 4.

Now let us consider a scenario where the ENDOW it variables are excluded from the model, this means the regression is addressing the following question: is it the component of the corruption index that is being explained by the exogenous endowments explain cross-country time variations in the logarithm of GDP per capita? This means if the value of $\delta$ is statistically significant, then it will suggest that those endowments do influence economic development through corruption index, which will, in turn, be consistent with the corruption hypothesis.

I have potential overidentification if the number of instruments exceeds the number of endogenous variables. In my analysis, the number of instruments is 4 and 1 endogenous variable. Let's still consider the scenario there is no CONTL $L_{i t}$ variables included in the model, using the Overidentifying Restrictions (OIR) test an important question is asked: does the endowments explaining the economic development is beyond the ability of endowments to explain in changes in corruption? More accurately, the OIR test has the null hypothesis that instrumental variables do not explain $v_{i t}$. For us it's it means that the endowments fail to explain the average logarithm of GDP per capita beyond the ability of endowments to explain corruption. Which simply means that it can't explain GDP per capita without the help of Corruption index. The OIR test produces a Lagrange multiplier test statistic which has the null hypothesis and has a Chi-squared $(\mathrm{m})$ distribution, where $\mathrm{m}$ is the number of OIR under study. $m=$ number of OIR is equalled the number of excluded exogenous variables minus the number of endogenous variables included as a regressor in the second stage of the regression process.

In the scenario where $C O N T L_{i t}$ variable is included in the model, i.e. in the second-stage where the non-endowment instrumental variables are included, the OIR test becomes a general specification test of the validity of the instruments that included in the model. If the OIR test does not reject the hypothesis that the instruments could be excluded from the second-stage regression that will prove the point. These regressions with $C O N T L_{i t}$ is used to access the robustness of the findings when I control for other potential exogenous variables that determinants the economic development. 


\subsubsection{Results}

In table 5 the results of the two-stage least-squares regression results are plotted with the first-stage F-test's P-value and other test values. In the first-stage F-test has the null hypothesis that the instrumental variables do not explain any cross-country variation in corruption index. Furthermore, if the OIR test of Hansen $\mathrm{J}$ statistics is valid for all the instrument I can say that the instrument does manage to explain the cross-country variation in economic development beyond their ability to explain corruption. Table 5 represents the results using the corruption index, although the confirmation of the findings of each of the indicators of corruption index discussed before.

There are seven pairs of regression for each of the random effect and between effect model in my analysis and each pair of regression is divided into two steps. The first pair of regression (1 and 2) uses total area and latitude as instrumental variables. Because the total area managed to explain the development of most of the countries I use it with all the equations and try to find the correlation. In the odd number of equations, no control variables were included. The even equations include the CONTL $L_{i t}$ variables, i.e. legal origins, ethnicity, language and religion are included as exogenous variables. The OIR test in the second step examines the validity of the instruments, i.e. the instrumental variables explain economic development beyond their ability to account for cross-country variations in the corruption index. All the variables included in the models are natural. They affect GDP as well as corruption. Since in reality, it is impossible to find any instrument variable that is uncorrelated with the dependent variable my logic is that these endowments affect GDP through corruption. In the final stage it is widely examined whether these natural endowments managed to explain current level of economic development beyond their ability to explain changes in corruption index by focusing on another hypothesis such as the Cragg-Donald Wald F statistic, Kleibergen-Paap Wald F statistic, Stock-Yogo Weak ID test Critical Value $10 \%$ maximal IV size and Weak Instrument test.

My test results show that the exogenous component of the corruption index significantly managed to explain the growth in GDP in both of the models, which in turn is consistency with the corruption hypothesis. The corruption index at $1 \%$ level of significant enters in all of the regressions given in table 5 and proved to be statistically significant. The coefficients of the corruption are around 0.70 in all the regressions. When I control for legal origin, ethnic, language and religion the results also proved to be robust. Even though I alter the instrument variable sets the strong positive relationship between the corruption index and the economic development seems robust. Moreover, the instruments used in the model are proved to be valid ones: they are highly correlated with the corruption index as illustrated by the P-value of the first-stage F-test. Moreover, the test of the weak instruments rejects the null hypothesis that the instruments are a valid one. As we can see in table 5 corruption enters in all the equations at $1 \%$ significant level and the value and the sign of the coefficient are constant. The coefficient is around 0.70 . When I include all the instruments all the instruments stay significant. When I include the control variables the result does not change. Of all the control variables the only language is highly significant at $1 \%$ level in all the equations. 
The results obtained from table 5 explains that endowments do not explain economic development beyond the ability of endowments to explain the corruption index. More exactly, when the regression only considers the endowment variables are Total area, Latitude, landlocked and precipitation, the data never reject the hypothesis that endowments only explain the logarithm of GDP per capita through their ability to explain corruption index, which is similar with (Easterly and Levine, 2003). The hypothesis used in this research basically focus on the impact of endowment and corruption problem on productivity and efficiency. The weak identification test for each set of variables is rejected by $10 \%$ maximum IV size or IV bias of the (Stock and Yogo, 2005). Which means the instruments are not weakly identified. Finally, table 5 provides enough evidence that corruption hypothesis but no proof of endowment hypothesis. These historical endowments managed to explain corruption index which in turn help to explain economic development, i.e. GDP per capita differences in cross-country. The data used on this paper fails to reject the hypothesis that endowments only explain cross-country differences in the level of economic development through the ability of endowments to explain corruption.

\subsection{Robustness Test}

Table 6. Endowments, Corruption, Economic Policy (Exogenous) and GDP per capita: Two Stage Least Squares (2SLS)

\begin{tabular}{|c|c|c|c|c|c|c|c|c|}
\hline & 2SLS RE & 2SLS RE & 2SLS RE & 2SLS RE & 2SLS RE & 2SLS RE & 2SLS RE & 2SLS RE \\
\hline Models & 1 & 2 & 3 & 4 & 5 & 6 & 7 & 8 \\
\hline \multirow[t]{2}{*}{ Corruption } & $0.74 * * *$ & $0.65^{* * * *}$ & $0.81^{* * *}$ & $0.74 * * *$ & $0.77 * * *$ & $0.64 * * *$ & $0.89 * * *$ & $0.67 * * *$ \\
\hline & $(0.062)$ & $(0.082)$ & $(0.085)$ & $(0.109)$ & $(0.089)$ & $(0.114)$ & $(0.182)$ & $(0.207)$ \\
\hline \multirow[t]{2}{*}{ Inflation } & $-0.0003 * * *$ & -0.0003 & & & & & 0.002 & -0.001 \\
\hline & $(0.000)$ & $(0.0004)$ & & & & & $(0.007)$ & $(0.006)$ \\
\hline \multirow[t]{2}{*}{ Govt. Consumption } & & & -0.032 & -0.02 & & & -0.03 & -0.02 \\
\hline & & & $(0.019)$ & $(0.020)$ & & & $(0.030)$ & $(0.027)$ \\
\hline \multirow[t]{2}{*}{ Broad Money } & & & & & -0.0004 & -0.0001 & -0.003 & -0.001 \\
\hline & & & & & $(0.0004)$ & $(0.0003)$ & $(0.002)$ & $(0.003)$ \\
\hline \multirow[t]{2}{*}{ Legal Origin } & & -0.01 & & -0.00 & & 0.06 & & 0.05 \\
\hline & & $(0.081)$ & & $(0.085)$ & & $(0.087)$ & & $(0.093)$ \\
\hline \multirow[t]{2}{*}{ Ethnic } & & 0.32 & & 0.48 & & 0.42 & & 0.37 \\
\hline & & $(0.452)$ & & $(0.499)$ & & $(0.460)$ & & $(0.519)$ \\
\hline \multirow[t]{2}{*}{ Language } & & $-1.22 * * *$ & & $-1.18^{* * * *}$ & & $-1.25 * * *$ & & $-1.26^{* * *}$ \\
\hline & & $(0.359)$ & & $(0.389)$ & & $(0.396)$ & & $(0.426)$ \\
\hline \multirow[t]{2}{*}{ Religion } & & -0.31 & & -0.35 & & -0.25 & & -0.16 \\
\hline & & $(0.329)$ & & $(0.352)$ & & $(0.371)$ & & $(0.424)$ \\
\hline Hansen J Statistic & 0.7331 & 0.6736 & 0.9877 & 0.6747 & 0.8408 & 0.6494 & 0.9292 & 0.6006 \\
\hline Weak Instrument test & Reject & Reject & Reject & Reject & Reject & Not Reject & Not Reject & Not Reject \\
\hline Cragg-Donald Wald & 40.595 & 19.421 & 24.555 & 12.755 & 21.693 & 10.713 & 7.452 & 3.929 \\
\hline Kleibergen-Paap & 38.571 & 19.188 & 23.683 & 11.866 & 17.678 & 11.147 & 6.857 & 4.391 \\
\hline Stock-Yogo & 11.59 & 11.59 & 11.59 & 11.59 & 11.59 & 11.59 & 11.59 & 11.59 \\
\hline Observation & 2016 & 1946 & 2038 & 1969 & 1784 & 1714 & 1690 & 1631 \\
\hline
\end{tabular}

The dependent variable is the logarithm of GDP per capita. In these cross-country time-series regressions Two-Stage Least Squares, (2SLS) estimation is being used. The sample size is of 190 countries. The heteroskedasticity consistent robust and clustered by a country standard error in parenthesis and $* * *$ and $* * *$ indicates significance at $10 \%, 5 \%$ and $1 \%$ respectively. The constant term is omitted in the table. The endogenous variable is the CPI (corruption), a score of Transparency International. The score lies between 0 and 10. Three policy variables; 
Inflation is the consumer price index reflects the annual percentage change in the cost to the average consumer of acquiring a basket of goods and services that may be fixed or changed at specified intervals, such as yearly. Govt. Consumption is the general government final consumption expenditure includes all government current expenditures for purchases of goods and services (including compensation of employees). Broad Money is the sum of currency outside banks; demand deposits other than those of the central government; the time, savings, and foreign currency deposits of resident sectors other than the central government; bank and traveller's checks; and other securities such as certificates of deposit and commercial paper. The instrument variables those have been excluded from the second stage regression are as following Total area, Latitude. The total area is the logarithm of the sum of all land and water areas delimited by international boundaries and/or coastlines is the logarithm of the county size or area. Latitude is the absolute value of each county's latitude. The exogenous control variables that are included in some of the second stages of the regression are as following; Legal Origin legal traditions into giving different categories such as British common law, French civil law, German civil law, Scandinavian law, and socialist law. It is a composite variable. Ethnic is the probability that two randomly selected individuals are from a population belonged to different groups. Language is the number of the language is spoken in the country and this language index given by Alberto Alesina (2003). Religion identifies the percentage of the population of each country that belonged to the three most widely spread religions in the world. The numbers are in percentage (scale from 0 to 100). The three religions identified here are (1) Roman Catholic; (2) Protestant; and (3) Muslim. The residual is called "other Religions". Hansen J Statistics is the test for overidentification restrictions. Null hypothesis: instruments are valid. Weak instruments test: Null hypothesis instruments are weak. Which is calculated with the Cragg-Donald Wald $15 \%$ IV size. Coefficients are robust to heteroskedasticity and clustering on Country.

In this section to check the robustness of my result, I examine the effect of macroeconomic and fiscal policies such as Inflation, Government Consumption and Broad Money on economic development. I check this in two steps, in the first step I treat the three policy variables as exogenous in my regressions. Even though this procedure may be biased but this will help us to understand the statistical relationship between the economic policies and the development. Moreover, it will help us to understand the two-way the causal relationship between the economic policy and development. Secondly, I treat those economic policies as endogenous within my model by using the instrumental variables that have been used before in my analysis to control for potential simultaneity bias. With the help of these two procedures, I can conclude whether the economic policy can explain the difference of development among nations.

When I treat economic policy as an exogenous variable in my model it does not help us to explain economic development after accounting for the impact of the corruption on economic development. In Table 6 I include the policy variables as exogenous and try to see whether these policy variables have any effect on economic development. The corruption index has $1 \%$ significant level in all the regression and the coefficient is almost unchanged. Comparing the result with table 7 which did not include those policy variables the result is unchanged. From this, I can conclude that even though when I control for policy variables the endowments managed to explain the cross-country differences in economic development through their effect on corruption. Moreover, in all the regressions the data never managed to reject the OIR-test which is given by the Hansen J statistics in my table 5.5. Furthermore, the policy variables are individually insignificant in all the regression except for regression 1; however, the coefficient is also very low. When I include all the policy variables together in regression 7 and 8 the F-test never reject the null hypothesis that the three policies all enter the regression with coefficients equal to zero. My weak instruments test for $15 \%$ maximum IV 
Table 7. Endowments, Corruption, Economic Policy (Endogenous) and GDP per capita: Two Stage Least Squares (2SLS)

\begin{tabular}{|c|c|c|c|c|c|c|}
\hline & 2SLS RE & 2SLS RE & 2SLS RE & 2SLS RE & 2SLS RE & 2SLS RE \\
\hline Models & 1 & 2 & 3 & 4 & 5 & 6 \\
\hline \multirow[t]{2}{*}{ Corruption } & $0.79 * * *$ & $0.62 * * *$ & $1.08 * *$ & -0.48 & $0.78 * * *$ & $0.63 * * *$ \\
\hline & $(0.117)$ & $(0.085)$ & $(0.524)$ & $(4.736)$ & $(0.114)$ & $(0.183)$ \\
\hline \multirow[t]{2}{*}{ Inflation } & 0.007 & -0.004 & & & & \\
\hline & $(0.012)$ & $(0.006)$ & & & & \\
\hline \multirow[t]{2}{*}{ Govt. Consumption } & & & -0.18 & 0.64 & & \\
\hline & & & $(0.309)$ & $(2.673)$ & & \\
\hline \multirow[t]{2}{*}{ Broad Money } & & & & & -0.005 & -0.003 \\
\hline & & & & & $(0.008)$ & $(0.008)$ \\
\hline \multirow[t]{2}{*}{ Legal Origin } & & -0.06 & & -0.14 & & 0.03 \\
\hline & & $(0.126)$ & & $(0.629)$ & & $(0.125)$ \\
\hline \multirow[t]{2}{*}{ Language } & & $-1.17 * * *$ & & -1.79 & & -0.91 \\
\hline & & $(0.401)$ & & $(3.351)$ & & $(0.791)$ \\
\hline \multirow[t]{2}{*}{ Religion } & & -0.03 & & -0.51 & & -0.06 \\
\hline & & $(0.558)$ & & $(1.504)$ & & $(0.595)$ \\
\hline Hansen J Statistic & 0.5663 & 0.8141 & 0.9772 & 0.8702 & 0.7001 & 0.3933 \\
\hline Weak Instrument test & Not Reject & Not Reject & Not Reject & Not Reject & Not Reject & Not Reject \\
\hline Cragg-Donald Wald & 0.216 & 0.379 & 0.285 & 0.019 & 0.205 & 0.131 \\
\hline Kleibergen-Paap & 0.584 & 0.376 & 0.276 & 0.016 & 0.333 & 0.219 \\
\hline Stock-Yogo & 13.43 & 13.43 & 13.43 & 13.43 & 13.43 & 13.43 \\
\hline Observation & 1995 & 1946 & 2028 & 1969 & 1763 & 1714 \\
\hline
\end{tabular}

The dependent variable is the logarithm of GDP per capita. In these cross-country time-series regressions Two-Stage Least Squares, (2SLS) estimation is being used. The sample size is of 190 countries. The heteroskedasticity consistent robust and clustered by a country standard error in parenthesis and $*, * *$ and $* * *$ indicates significance at $10 \%, 5 \%$ and $1 \%$ respectively. The constant term is omitted in the table. The endogenous variable is the CPI (corruption), a score of Transparency International. The score lies between 0 and 10 . Three policy variables that are treated as endogenous are; Inflation is the consumer price index reflects the annual percentage change in the cost to the average consumer of acquiring a basket of goods and services that may be fixed or changed at specified intervals, such as yearly; Govt. Consumption is the general government final consumption expenditure includes all government current expenditures for purchases of goods and services (including compensation of employees)and Broad Money is the sum of currency outside banks; demand deposits other than those of the central government; the time, savings, and foreign currency deposits of resident sectors other than the central government; bank and traveler's checks; and other securities such as certificates of deposit and commercial paper. The instrument variables those have been excluded from the second stage regression are as following Total area, Latitude and Ethnicity. The total area is the logarithm of the sum of all land and water areas delimited by international boundaries and/or coastlines is the logarithm of the county size or area. Latitude is the absolute value of each county's latitude. Ethnic is the probability that two randomly selected individuals are from a population belonged to different groups. The exogenous control variables that are included in some of the second stages of the regression are as following; Legal Origin legal traditions into giving different categories such as British common law, French civil law, German civil law, Scandinavian law, and socialist law. It is a composite variable. Language is the number of the language is spoken in the country and this language index given by Alberto Alesina (2003). Religion identifies the percentage of the population of each country that belonged to the three most widely spread religions in the world. The numbers are in percentage (scale from 0 to 100). The three religions identified here are (1) Roman Catholic; (2) Protestant; and (3) Muslim. The residual is called "other Religions". Hansen J Statistics is the test for overidentification restrictions. Null hypothesis: instruments are valid. Weak instruments test: Null hypothesis instruments are weak. Which is calculated with the Cragg-Donald Wald $101 \%$ IV size. Coefficients are robust to heteroskedasticity and clustering on Country.

size also fails to reject the null hypothesis that the instruments are weak in those equations. 
When I use the policy variables as endogenous with the corruption, I find that these policies do not manage to explain economic development across countries. More specifically, I fail to reject the hypothesis that economic policies do not have any impact of economic development after I consider the impact of endowments and corruption. In table 5.5 I include ethnic diversity as an instrumental variable. I include ethnic diversity because (Easterly, William and Levine, 2003; Easterly \& Levine, 1997; La Porta et al., 1999) find that ethnic diversity can help to explain differences in government policies. Same as in the previous regressions the instrumental variables managed to explain a significant amount of cross-country variation in the corruption index. However, in the case of policy, the instruments do not manage to explain the cross-country differences in policy. All the policy variables are insignificant and the coefficient is very small. Thus I can conclude that the exogenous components of corruption index can significantly define the cross-country variation in economic development however the economic policy does not indicate any additional explanatory power.

\section{Conclusion}

In my study, I observe the consequence of corruption to economic development considering the geographic factors which one is the main factor determining growth. With the support of empirical evidence provided in the literature the answer to the research question stated in the previous sections consistency. In the presence of corruption, large geographic endowments may not result in growth. Therefore, the policymaker should pay much attention to combating corruption before imposing suitable policies.

By using a large sample of countries for over the past two decades it's been shown in the research again the bad effect of corruption. Using the data Wold Bank and Transparency International I find that countries facing higher corruption in the institutions might be underdeveloped. Corruption is a problem of institutions and institutions determine the economics process and plans. In sum, it's affecting all the aspect of life in an economy. For the possible existence of endogeneity between the corruption and GDP per capita, I use 2SLS with random effect model. Although there is no perfect solution to address the problem of endogeneity I do my best to use panel data with 2SLS to control the problem. This is merely one of many procedures to solve for the problem of endogeneity. Moreover, I consider the historical and cultural factors by using legal origin, ethnicity, language and religion variable and use them as a control variable in my analysis. The results of my analysis showed that natural endowments don't matter for development as long as corruption is in the middle. Because natural endowments affect GDP per capita through their impact on corruption.

I should also consider the limitations of failure to reject zero coefficient or an exclusion restriction and not put too much emphasis on the result. Strict rules and regulations or strong law and justice system may be able to solve the problem of corruption. This kind of regression results should be tested and studied further according to the culture and historical case studies of international development strategies. The results of my panel regressions only tell the story of colonial experiences, cultural differences, institutional problems, geographical divergences and economic development for each unique case. In spite of I am 
restricted by the endowments and historical factors, corruption can be a good measure of institutional quality to economic development. I would like to point out several limitations of my research. First, there determinants and consequences of corruption (institutional effectiveness) are broadly defined. I do not use another indicator that captures specific dimensions. Second, most of the instruments used in the analysis are fixed in nature. It's hard to determine the time-varying effect. Third, I only focus on corruption while controlling for historical and cultural factors. Fourth, my research does not include policy implication. I propose further research should be done on this limitation.

A lot of literature proposed a possible solution to corruption. Quade (2007) proposed that the aforementioned anti-corruption campaigns have been used primarily to combat economic overheating and not corruption itself. Another way to reduce corruption is by monitoring the bureaucrats, Coppier, Costantini, and Piga (2013) shows that there is a nonlinear relationship between the level of State monitoring and economic growth. Koyuncu, Ozturkler, and Yilmaz (2010) shows that there is a highly statistically significant and negative association between privatization and corruption in transition economies. But Arikan (2008) analyzed an unbalanced data set of 73 countries from 1985 to 2005 and find that higher privatization levels lea to an increase in corruption.

\section{References}

Acemoglu, D., Johnson, S., \& Robinson, J. A. (2002). Reversal of Fortune: Geography and Institutions in the Making of the Modern World Income Distribution. The Quarterly Journal of Economics, 117(4), 1231-1294. https://doi.org/10.1162/003355302320935025

Acemoglu, D., Johnson, S., \& Robinson, J. A. (2012). The colonial origins of comparative development: An empirical investigation: Reply. American Economic Review. https://doi.org/10.1257/aer.102.6.3077

Ades, A., \& Di Tella, R. (1997). The new economics of corruption: A survey and some new results. Political Studies, 45(3), 496-515. https://doi.org/10.1111/1467-9248.00093

Al-Marhubi, F. A. (2000). Corruption and inflation. Economics Letters, 66(2), 199-202. https://doi.org/10.1016/S0165-1765(99)00230-X

Alatas, H. (1990). Corruption: its nature, causes, and functions. Avebury.

Alesina, A., Devleeschauwer, A., Easterly, W., Kurlat, S., \& Wacziarg, R. (2003). Fractionalization. Journal of Economic Growth, 8(2), 155-194.

https://doi.org/10.1023/A:1024471506938

Ali, A. M., \& Isse, H. S. (2002). Determinants of economic corruption: a cross-country comparison. Cato J., 22, 449.

Arezki, R., \& Brückner, M. (2011). Oil rents, corruption, and state stability: Evidence from panel data regressions. European Economic Review, 55(7), 955-963.

https://doi.org/10.1016/j.euroecorev.2011.03.004

Arikan, G. G. (2008). How privatizations affect the level of perceived corruption. Public 
Finance Review. https://doi.org/10.1177/1091142107313302

Balachandrudu, K. (2006). Understanding Political Corruption. The Indian Journal of Political Science, 809-816.

Beck, T., \& Asli Demirgüç-Kunt, R. L. (2003). Law and finance: why does legal origin matter?. Journal of Comparative Economics, 31(4), 653-675.

https://doi.org/10.1016/j.jce.2003.08.001

Beck, T., Demirgüç-Kunt, A., \& Levine, R. (2003). Law, endowments, and finance. Journal of Financial Economics, 70(2), 137-181. https://doi.org/10.1016/S0304-405X(03)00144-2

Beck, T., \& Laeven, L. (2006). Institution building and growth in transition economies. Journal of Economic Growth, 11(2), 157-186. https://doi.org/10.1007/s10887-006-9000-0

Brunnschweiler, C. N. (2008). Cursing the blessings? Natural resource abundance, institutions, and economic growth. World Development, 36(3), 399-419.

https://doi.org/10.1016/j.worlddev.2007.03.004

Bulte, E. H., Damania, R., \& Deacon, R. T. (2005). Resource intensity, institutions, and development. World Development, 33(7), 1029-1044.

https://doi.org/10.1016/j.worlddev.2005.04.004

Caballero, R. J., Cowan, K. N., Engel, E. M. R. A., \& Micco, A. (2013). Effective labor regulation and microeconomic flexibility. Journal of Development Economics, 101, 92-104. https://doi.org/10.1016/j.jdeveco.2012.08.009

Ciccone, A., \& Papaioannou, E. (2007). Red tape and delayed entry. Journal of the European Economic Association, 5(2-3), 444-458. https://doi.org/10.1162/jeea.2007.5.2-3.444

Coppier, R., Costantini, M., \& Piga, G. (2013). The Role of Monitoring of Corruption in a Simple Endogenous Growth Model. Economic Inquiry, 51(4), 1972-1985.

https://doi.org/10.1111/ecin.12007

Danon, M. (2011). Contemporary economic research of corruption. Contemporary Legal and Economic Issues, 3, 252.

Del Mar Salinas-Jiménez, M., \& Salinas-Jiménez, J. (2007). Corruption, efficiency and productivity in OECD countries. Journal of Policy Modeling, 29(6), 903-915. https://doi.org/10.1016/j.jpolmod.2007.07.002

Desai, R. M., Olofsgård, A., \& Yousef, T. M. (2005). Inflation and inequality: does political structure matter? Economics Letters, 87(1), 41-46.

https://doi.org/10.1016/j.econlet.2004.08.012

Diamond, J. M., \& Ordunio, D. (1997). Guns, germs, and steel. Books on Tape.

Dincer, O. C., \& Gunalp, B. (2008). Corruption, income inequality, and poverty in the United States.

Djankov, S., La Porta, R., Lopez-de-Silanes, F., \& Shleifer, A. (2002). The regulation of entry. 
The Quarterly Journal of Economics, 117(1), 1-37.

https://doi.org/10.1162/003355302753399436

Dobson, S., \& Ramlogan-Dobson, C. (2012). Why is corruption less harmful to income inequality in Latin America? World Development, 40(8), 1534-1545.

https://doi.org/10.1016/j.worlddev.2012.04.015

Dong, B., \& Torgler, B. (2012). Corruption and social interaction: Evidence from China. Journal of Policy Modeling, 34(6), 932-947. https://doi.org/10.1016/j.jpolmod.2012.04.005

Downes, A. S. (1988). On the statistical measurement of smallness: a principal component measure of country size. Social and Economic Studies, 75-96.

Easterly, William and Levine, R. (2003). Tropics, germs, and crops: How endowments influence economic development. Journal of Monetary Economics.

https://doi.org/10.1016/S0304-3932(02)00200-3

Easterly, W., \& Levine, R. (1997). Africa's growth tragedy: policies and ethnic divisions. The Quarterly Journal of Economics, 112(4), 1203-1250.

https://doi.org/10.1162/003355300555466

Engerman, S. L., \& Sokoloff, K. L. (2002). Factor endowments, inequality, and paths of development among new world economics.

Freund, C., \& Bolaky, B. (2007). When does trade promote growth?

Galbraith, J. K. (1951). Conditions for Economic Change in Underdeveloped Countries. Journal of Farm Economics, 33, 689-696. https://doi.org/10.2307/1233431

Gallup, J. L., \& Sachs, J. D. (2000). Agriculture, climate, and technology: Why are the tropics falling behind? American Journal of Agricultural Economics, 82(3), 731-737.

Gennaioli, N., La Porta, R., De Silanes, F. L., \& Shleifer, A. (2014). Growth in regions. Journal of Economic Growth, 19(3), 259-309. https://doi.org/10.1007/s10887-014-9105-9

Glaeser, E. L., La Porta, R., Lopez-de-Silanes, F., \& Shleifer, A. (2004). Do institutions cause growth? Journal of Economic Growth, 9(3), 271-303.

https://doi.org/10.1023/B:JOEG.0000038933.16398.ed

Graeff, P., \& Svendsen, G. T. (2013). Trust and corruption: The influence of positive and negative social capital on the economic development in the European Union. Quality \& Quantity, 47(5), 2829-2846. https://doi.org/10.1007/s11135-012-9693-4

Greenberg, M. R., Carey, G. W., Zobler, L., \& Hordon, R. M. (1971). A geographical systems analysis of the water supply networks of the New York metropolitan region. Geographical Review, 339-354. https://doi.org/10.2307/213432

Gupta, S., Davoodi, H., \& Alonso-Terme, R. (2002). Does corruption affect income inequality and poverty? Economics of Governance, 3(1), 23-45.

https://doi.org/10.1007/s101010100039 


\section{Macrothink}

Business and Economic Research ISSN 2162-4860 2019, Vol. 9, No. 1

Gyimah-Brempong, K., \& de Gyimah-Brempong, S. M. (2006). Corruption, growth, and income distribution: Are there regional differences? Economics of Governance, 7(3), 245-269. https://doi.org/10.1007/s10101-005-0008-2

Iyigun, M. (2005). Geography, demography, and early development. Journal of Population Economics, 18(2), 301-321. https://doi.org/10.1007/s00148-004-0212-3

Kaufman, D. (1997). Corruption: The facts foreign policy. In IMF Staff Seminar.

Kaufmann, D., Kraay, A., \& Zoido-Lobatón, P. (1999). Aggregating governance indicators (Vol. 2195). World Bank Publications. https://doi.org/10.2139/ssrn.188548

Koyuncu, C., Ozturkler, H., \& Yilmaz, R. (2010). Privatization and corruption in transition economies: a panel study. Journal of Economic Policy Reform, 13(3), 277-284.

https://doi.org/10.1080/17487870.2010.503099

La Porta, Rafael and Lopez-de-Silanes, Florencio and Shleifer, A. (2008). The economic consequences of legal origins. Journal of Economic Literature, 46(2), 285-332. https://doi.org/10.1257/jel.46.2.285

La Porta, R., Lopez-de-Silanes, F., \& Shleifer, A. (2002). Government ownership of banks. The Journal of Finance, 57(1), 265-301. https://doi.org/10.1111/1540-6261.00422

La Porta, R., Lopez-de-Silanes, F., Shleifer, A., \& Vishny, R. (1999). The quality of government. Journal of Law, Economics, and Organization, 15(1), 222-279.

https://doi.org/10.1093/jleo/15.1.222

La Porta, R., Lopez-de-Silanes, F., Shleifer, A., \& Vishny, R. W. (1997). Legal determinants of external finance. Journal of Finance, 1131-1150.

https://doi.org/10.1111/j.1540-6261.1997.tb02727.x

Leeson, P. T., \& Sobel, R. S. (2008). Weathering corruption. The Journal of Law and Economics, 51(4), 667-681. https://doi.org/10.1086/590129

Levy, D. (2007). Price adjustment under the table: Evidence on efficiency-enhancing corruption. European Journal of Political Economy, 23(2), 423-447.

https://doi.org/10.1016/j.ejpoleco.2007.01.001

Li, H., Xu, L. C., \& Zou, H. (2000). Corruption, income distribution, and growth. Economics \& Politics, 12(2), 155-182. https://doi.org/10.1111/1468-0343.00073

Limao, N. (2001). Infrastructure, Geographical Disadvantage, Transport Costs, and Trade. The World Bank Economic Review, 15(3), 451-479. https://doi.org/10.1093/wber/15.3.451

Lui, F. T. (1985). An equilibrium queuing model of bribery. Journal of Political Economy, 93(4), 760-781. https://doi.org/10.1086/261329

Machiavelli, N. (n.d.). 1519 [1987]. Discourses on Livy.

Mauro, P. (1995). Corruption and growth. The Quarterly Journal of Economics, 110(3), 681-712. https://doi.org/10.2307/2946696 
Mitchell, T. D., CARTER, T. R., JONES, P. D., HULME, M., \& NEW, M. (2003). A comprehensive set of climate scenarios for Europe and the Globe. Tyndall Centre for Climate Change Research. preparation. https://doi.org/10.1023/A:1026035305597

Montesquieu, C., \& de Secondat, C. (n.d.). 1748/1989. The Spirit of the Laws.

Nasir, A. B. M. (2011). Nexus between inflation rates and institutional rigidities in Bangladesh: An overlooked aspect for the cause of inflation. The Journal of Developing Areas, 45(1), 339-358. https://doi.org/10.1353/jda.2011.0005

Newman, J. L. (1973). The Use of the Term "hypothesis" in Geography. Annals of the Association of American Geographers, 63(1), 22-27.

https://doi.org/10.1111/j.1467-8306.1973.tb00901.x

North, D. C. (1981). Structure and change in economic history. Norton.

Porta, R. La, Lopez-de-Silanes, F., Shleifer, A., \& Vishny, R. W. (1998). Law and finance. Journal of Political Economy, 106(6), 1113-1155. https://doi.org/10.1086/250042

Quade, E. A. (2007). The logic of anticorruption enforcement campaigns in contemporary China. Journal of Contemporary China, 16(50), 65-77.

https://doi.org/10.1080/10670560601026751

Rodrik, D., Subramanian, A., \& Trebbi, F. (2004). Institutions rule: the primacy of institutions over geography and integration in economic development. Journal of Economic Growth, 9(2), 131-165. https://doi.org/10.1023/B:JOEG.0000031425.72248.85

Rose-Ackerman, S., \& Palifka, B. J. (2016). Corruption and government: Causes, consequences, and reform. Cambridge university press.

https://doi.org/10.1017/CBO9781139962933

Rostowski, J., Stacescu, B., \& others. (2006). The Wig and the Pith Helmet-the Impact of" Legal School" versus Colonial Institutions on Economic Performance (second version).

Sachs, Jeffrey D and Warner, A. M. (2001). The curse of natural resources. European Economic Review, 45(4), 827-838. https://doi.org/10.1016/S0014-2921(01)00125-8

Sachs, J. D., \& Warner, A. M. (1995). Natural resource abundance and economic growth.

Sah, R. K. (1988). Persistence and pervasiveness of corruption: new perspectives.

Sala-i-Martin, X., \& Subramanian, A. (2008). Addressing the natural resource curse: An illustration from Nigeria. In Economic Policy Options for a Prosperous Nigeria (pp. 61-92). Springer. https://doi.org/10.1057/9780230583191_4

Salinas, F. J., \& Jiménez, M. del M. S. (2007). Does corruption affect efficiency and productivity change? an aggregate frontier analysis. In XIV Encuentro de Econom $\uparrow \backslash i\} a$ Pública: pol^ \i\}ticas públicas y reformas fiscales (p. 53).

Sokoloff, K. L., \& Engerman, S. L. (2000). History lessons: Institutions, factors endowments, and paths of development in the new world. The Journal of Economic Perspectives, 14(3), 
217-232. https://doi.org/10.1257/jep.14.3.217

Swaleheen, M. U. (2007). Corruption and investment choices: a panel data study.

Teorell, J., Dahlberg, S., Holmberg, S., Rothstein, B., Hartmann, F., \& Svensson, R. (2015). The Quality of Government Standard Dataset, version Jan15. University of Gothenburg: The Quality of Government Institute.

Thorsten, C.-C. E., Beck, T., Demirguc-kunt, A., \& Levine, R. (2005). SMEs, Growth, and Poverty. In Journal of economic growth.

Wei, S.-J. (2000). How taxing is corruption on international investors? Review of Economics and Statistics, 82(1), 1-11. https://doi.org/10.1162/003465300558533

Wietzke, F.-B. (2015). Long-term consequences of colonial institutions and human capital investments: Sub-national evidence from Madagascar. World Development, 66, 293-307. https://doi.org/10.1016/j.worlddev.2014.08.010

\section{Appendix}

Appendix 1

\begin{tabular}{|c|c|c|c|}
\hline $\begin{array}{l}\text { Variable } \\
\text { Name }\end{array}$ & Type & Description & Source \\
\hline $\begin{array}{l}\text { GDP per } \\
\text { capita }\end{array}$ & Dependent & $\begin{array}{l}\text { GDP per capita is gross domestic product divided by } \\
\text { midyear population. }\end{array}$ & WB (2016) \\
\hline Corruption & $\begin{array}{l}\text { Endogenous } \\
\text { explanatory } \\
\text { variable }\end{array}$ & $\begin{array}{l}\text { The Corruption Perceptions Index (CPI) ranks countries } \\
\text { and territories based on how corrupt their public sector is } \\
\text { perceived to be. }\end{array}$ & TI (2015) \\
\hline Total Area & $\begin{array}{l}\text { Key } \\
\text { Instrument in } \\
\text { IV regression }\end{array}$ & $\begin{array}{l}\text { The total area is the sum of the logarithm of all land and } \\
\text { water areas delimited by international boundaries and/or } \\
\text { coastlines. }\end{array}$ & CIA (2014) \\
\hline Latitude & $\begin{array}{l}\text { Key } \\
\text { Instrument in } \\
\text { IV regression }\end{array}$ & Latitude is the absolute value of the latitude of the country. & $\begin{array}{l}\text { Gennaioli et } \\
\text { al. (2014) }\end{array}$ \\
\hline Landlocked & $\begin{array}{l}\text { Key } \\
\text { Instrument in } \\
\text { IV regression }\end{array}$ & $\begin{array}{l}\text { Landlocked is simply a dummy value that takes on the } \\
\text { value } 0 \text { if the country has coastal territory on the world's } \\
\text { oceans, and } 1 \text { in otherwise. }\end{array}$ & CIA (2014) \\
\hline Precipitation & $\begin{array}{l}\text { Key } \\
\text { Instrument in } \\
\text { IV regression }\end{array}$ & $\begin{array}{l}\text { Precipitation refers to the total volume of atmospheric wet } \\
\text { deposition (rain, snow, hail, dew, etc) falling on the } \\
\text { territory of the country over one year, in millions of cubic } \\
\text { meters. Collected from three different sources and own } \\
\text { calculation. }\end{array}$ & $\begin{array}{l}\text { WB (2016), } \\
\text { Mitchell et al. } \\
(2003), \quad \text { UN } \\
(2014)\end{array}$ \\
\hline Legal Origin & Control & $\begin{array}{l}\text { Identifies the legal origin of the Company Law or } \\
\text { Commercial code of each country. There are five possible } \\
\text { origins: British common law, French civil law, German }\end{array}$ & $\begin{array}{l}\text { Gennaioli et } \\
\text { al. (2014) }\end{array}$ \\
\hline
\end{tabular}




\begin{tabular}{|c|c|c|c|}
\hline & & civil law, Scandinavian law, and socialist law. & \\
\hline Ethnicity & Control & $\begin{array}{l}\text { The probability that two randomly selected individuals are } \\
\text { from a population belonged to different groups. }\end{array}$ & $\begin{array}{l}\text { Alesina et al. } \\
(2013)\end{array}$ \\
\hline Language & Control & $\begin{array}{l}\text { Language is another way to look at the ethnic diversity but } \\
\text { not the only way because in many countries in South } \\
\text { American language is homogeneous but they } \\
\text { heterogeneous. }\end{array}$ & $\begin{array}{l}\text { Alesina et al. } \\
(2013)\end{array}$ \\
\hline Religion & Control & $\begin{array}{l}\text { Identifies the percentage of the population of each country } \\
\text { that belonged to the three most widely spread religions in } \\
\text { the world in 1980. The numbers are in percentage (scale } \\
\text { from } 0 \text { to 100). The three religions identified here are (1) } \\
\text { Roman Catholic; (2) Protestant; and (3) Muslim. The } \\
\text { residual is called "other Religions". }\end{array}$ & $\begin{array}{l}\text { Alesina et al. } \\
(2013)\end{array}$ \\
\hline Inflation & Policy & $\begin{array}{l}\text { Inflation, as measured by the consumer price index, reflects } \\
\text { the annual percentage change in the cost to the average } \\
\text { consumer of acquiring a basket of goods and services that } \\
\text { may be fixed or changed at specified intervals, such as } \\
\text { yearly. }\end{array}$ & WB (2016) \\
\hline $\begin{array}{l}\text { Govt. } \\
\text { Consumption }\end{array}$ & Policy & $\begin{array}{l}\text { General government final consumption expenditure } \\
\text { includes all government current expenditures for purchases } \\
\text { of goods and services (including compensation of } \\
\text { employees). It also includes most expenditures on national } \\
\text { defence and security but excludes government military } \\
\text { expenditures that are part of government capital formation. }\end{array}$ & WB (2016) \\
\hline Broad Money & Policy & $\begin{array}{l}\text { Broad money is the sum of currency outside banks; demand } \\
\text { deposits other than those of the central government; the } \\
\text { time savings, and foreign currency deposits of resident } \\
\text { sectors other than the central government; bank and } \\
\text { traveller's checks; and other securities such as certificates } \\
\text { of deposit and commercial paper. }\end{array}$ & WB (2016) \\
\hline
\end{tabular}

\section{Copyright Disclaimer}

Copyright for this article is retained by the author(s), with first publication rights granted to the journal.

This is an open-access article distributed under the terms and conditions of the Creative Commons Attribution license (http://creativecommons.org/licenses/by/3.0/). 